\title{
"Esprimere la voce humana": Connections between Vocal and Instrumental Music by Italian Composers of the Early Seventeenth Century
}

\author{
REBECCA CYPESS
}

Of all the musical instruments how truly marvelous is the nature of the violin: for none other, with such a small body, and so few strings, contains such a great diversity of sounds, harmonies, and melodic ornaments; and [none other] better expresses the human voice, not only in song (in which some wind instruments may also succeed) but in speech itself; this one imitates so well in those quick accents, when it [the violin] is managed by an adept hand, that it is a thing of wonder ... ${ }^{1}$

\begin{abstract}
An earlier version of this essay was presented at the 2007 meeting of the Society for Seventeenth-Century Music. The author wishes to express her gratitude to Gregory Barnett, Sandra Cypess, Beth Glixon, Robert Holzer, Ellen Rosand, Craig Wright, and Neal Zaslaw for their insightful comments and suggestions.
\end{abstract}

1 "Frà tutti gl'instrumenti musicali maravigliosa veramente è la natura del violino: poiche niuno ve n'hà che in tanta picciolezza di corpo, e paucità di corde, contenga così gran diversità di suoni, d'Armonie, \& d'ornamenti melodici; e che meglio esprima la voce humana, non solo nel canto (nel che comunica pure con alcuni strumenti da fiato) mà nella favella istessa: la quale imita così bene in quei velocissimi accenti, quando da perita mano vien maneggiato, ch'è cosa degna di stupore . . ." Giovanni Battista Doni, Annotazioni sopra il compendio de' generi e de' modi della musica (Rome: Andrea Fei, 1640), 337. Translation mine. Doni was neither the first nor the last to claim that an instrument could imitate the voice. Indeed, sixteenth-century theorists seem to have considered the emulation of song a necessity for all instrumentalists. See Anthony Rooley, "Ficino, and the Supremacy of Poetry over Music," in Le concert des voix et des instruments à la Renaissance: Actes du XXXIVe colloque international d'études humanistes, Tours, Centre d'études supérieures de la Renaissance, I-I I juillet I99I, ed. Jean-Michel Vaccaro (Paris: CNRS, 1995), 51-6.

The Journal of Musicology, Vol. 27, Issue 2, pp. 181-223, ISSN 0277-9269, electronic ISSN 1533-8347. (C) 2010 by the Regents of the University of California. All rights reserved. Please direct all requests for permission to photocopy or reproduce article content through the University of California Press's Rights and Permissions website, http://www.ucpressjournals.com/reprintInfo.asp. DOI: 10.1525/ jm.2010.27.2.181. 


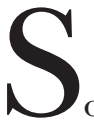

o wrote Giovanni Battista Doni in 1640 , at the end of the first period of innovation and experimentation with the violin undertaken by Italian composers between approximately 1610 and $1640 .^{2}$ In the 1620 s in particular, composers began to explore the technical, sonic, and expressive possibilities of the instrument, embracing its capacity for affective animation, and in some cases exploiting its physical construction in unusual, even awkward manners to expand the instrument's dramatic potential.

At the heart of the passage quoted above is Doni's comparison between the violin and human voice: the instrument, Doni claims, is capable of imitating not only song, but also favella (speech). Although the meaning of favella is frustratingly vague in this context (it can refer to the faculty of speech, a discourse, a manner of speaking, or language itself), it seems possible that Doni is alluding to the violin's communicative power, akin to that of speech. Even in the absence of words, the violin in the hands of a virtuoso may convey meaning, arousing in the audience a sense of meraviglia (amazement) at the transformation of such a small instrument into a vehicle for the communication of affetti. According to Doni it is the violin's ability to produce a "great diversity of sounds" that allows it to imitate speech, a statement that indicates that the essence of favella lies mainly in contrast. Indeed, as discussions of works by Biagio Marini (1594-1663), Dario Castello (early 17 th century), Girolamo Frescobaldi $\left(15^{8} 3^{-1643)}\right.$, and Carlo Farina (c. 16o41639) will show, contrast and changeability were essential elements of the instrumental stile moderno. ${ }^{3}$

Although relatively few writers of the early seventeenth century left extensive verbal descriptions of the theories or performance practices of instrumental music, the published compositions themselves-together with their titles, rubrics, prefaces, and dedications-offer evidence concerning the stylistic changes taking place in that repertoire. Salamone Rossi (1570-1630), Castello, and Marini use the word moderno to refer

${ }^{2}$ A distinction should be made between music composed in Italy and music by Italian composers. Some of the innovators of the new violin techniques were Italians employed in Germany, apparently responding to the interests of their patrons in German courts, as will be discussed further below.

3 Andrew Dell'Antonio's detailed analyses of collections of instrumental music published between 1621 and 1635 have shown that composers drew upon a set of common materials and formal procedures in the development of stile-moderno instrumental genres. The present discussion builds on Dell'Antonio's findings, but focuses on the surface features of the music, which embrace a spirit of discontinuity and capriciousness, even though the musical components of the works fall into fairly predictable categories. See Andrew Dell'Antonio, Syntax, Form, and Genre in Sonatas and Canzonas, I 62 I-I 635 (Lucca: Libreria Musicale Italiana, 1997). 
to individual or collected compositions, indicating that a dramatic shift was underway in the nature of instrumental music. ${ }^{4}$ Castello's two volumes of Sonate concertate in stil moderno $\left(1621^{5}\right.$ and $\left.1629^{6}\right)$ and Marini's Sonate, sinfonie, canzoni, pass'emezzi, baletti, corenti, gagliarde, E ${ }^{2}$ retornelli (1626), 7 which contained curiose e moderne inventioni (curious and modern inventions), both seem to associate the modern style with virtuosity - the physical agility required for quick passagework, double- and triple-stops, scordatura, and other novel techniques-in addition to the musical contrasts described by Doni. Girolamo Frescobaldi, Marini and Castello all use the rubrics affetto and affetti in instrumental works, identifying those sections that require either a highly emotive execution, or some creative ornamentation, or both.

The rise of a new style of instrumental music in the early Seicento overlapped with more well-known developments in vocal music, especially in the spheres of opera and solo song. Musicologists have long speculated about a possible connection between the emergence of vocal monody and opera and the repertoire of Italian solo instrumental music in the early decades of the seventeenth century. ${ }^{8}$ However, contemporary scholars have thus far only alluded to a general link, without articulating the precise nature of the relationship between these two bodies of music.

4 See Salamone Rossi, "Sonata prima detta la moderna," in Il terzo libro de varie sonate sinfonie, galiarde, brandi e corrente per sonar due viole da braccio, E̋ un chittarrone, o altro stromento simile (Venice: Vincenti, 1623/R). Modern edition in Salamone Rossi, Complete Works, ed. Don Harrán (Neuhausen: American Institute of Musicology, 1995-).

5 Dario Castello, Sonate concertate in stil moderno per sonar nel organo, overo spineta con diversi instrumenti, a 2 e 3 voci. Libro primo (Venice: Bartolomeo Magni, 1621 , reprinted in 1629 and twice in 1658; facsimile edition, Florence: Studio per Edizioni Scelte, 1979). Modern edition by Rudolf Hofstötter and Ingomar Rainer, Wiener Edition alter Musik, v. 2 (Vienna: Doblinger, 1998). My thanks to Andrew Dell'Antonio for calling my attention to the extant copy of the first edition of Castello's libro primo of 1621 , previously thought to have been lost entirely, in the Jagellonian Library, Krakow (PL-Kj).

6 Dario Castello, Sonate concertate in stil moderno per sonar nel organo overo clavicembalo con diversi instrumenti a I.2.3 e 4 voci. Libro secondo (Venice: Bartolomeo Magni, 1629; 1644/R; facsimile edition, Florence: Studio per Edizioni Scelte, 1981). Modern edition by Rudolf Hofstötter and Ingomar Rainer, Wiener Edition alter Musik, v. 3 (Vienna: Doblinger, 1998).

7 Biagio Marini, Sonate, symphonie, canzoni, pass'emezzi, baletti, corenti, gagliarde, Ẽ retornelli, a I. 2. 3. 4. 5. E 6. voci, per ogni sorte di strumenti. Un capriccio per sonar due violini quatro parti. Un eco per tre violini $\mathcal{E}$ alcune sonate capricciose per sonar due e tre parti con il violino solo, con altre curiose $\mathcal{E}^{2}$ moderne inventioni. Opera VIII (Venice: Bartolomeo Magni, [1626]); facsimile edition, Florence: Studio per Edizioni Scelte, 2004). Modern edition by Maura Zoni (Milan: Edizioni Suvini Zerboni, 2004). Musical examples from this volume that appear in the present essay are based in part on Zoni's edition. The publication date of this volume, most often thought to be 1629 , is a matter of some debate, to be addressed below.

8 See, for example, Simon McVeigh, "The Violinists of the Baroque and Classical Periods," in The Cambridge Companion to the Violin, ed. Robin Stowell (Cambridge: Cambridge University Press, 1992), 46 and 48 . 
Three areas of overlap seem especially suggestive. First, like books of vocal monody with an overt pedagogical purpose, volumes of instrumental music may have been designed to instruct the performer in the conventions of the new style. Specifically, many books published in the 161 os and '2os offer their users a window on the changeable, fluid idiom of the stile moderno, in which musical contrast and invention assume primary importance. Second, as in recitative and other vocal genres, much of the vocal and instrumental music of the early seventeenth century is dominated by a metrical flexibility that contributes to a similar air of immediacy, and that seems designed to highlight the emotional qualities of the music, in other words to convey and move the affetti. And third, some instrumental music of the period may be just as theatrical as the dramatic vocal music of the time, containing instructions for interaction with an audience, staging, imitation, and role-play.

These points of intersection in particular suggest a relationship between the instrumental stile moderno and the vocal stile rappresentativo, prevalent in operas, ensemble madrigals, and solo songs in the early 1600 . Although no single, exclusive definition of the stile rappresentativo exists, it is nevertheless possible to trace a constellation of features associated with that term through a variety of works. ${ }^{9}$ Despite the divergence of the specific musical language of the vocal and instrumental repertoires, some of the vocal features are analogous to elements of instrumental music outlined below.

It might at first seem implausible that instrumental music could convey specific programmatic meanings, an apparently essential feature of the vocal stile rappresentativo. And yet, as Peter Allsop notes, Athanasius Kircher's Itinerarium extaticum $\left(1_{5} 6\right)$ implies that instrumental music, apparently independent of any clear program, could also be interpreted as representational. Describing a recent performance of instrumental music, Kircher's interlocutor Theodidacticus says,

[As the performers] descended through the octave from high to low they became gradually more gentle, thus affecting the senses of the listeners with similar languor. . . . sometimes, with low sounds of sorrowful disdain, they drew forth a mood of melancholy and sorrow, as if engaged in a tragic event . . . Little by little, they began to pass into more

9 Tim Carter, among others, has noted the difficulty of defining the precise meaning of the stile rappresentativo: "Exactly what is represented in the stile rappresentativo (the emotions, the text, the act of representation itself?) is open to debate." Although Carter does not pursue this line of inquiry, his three suggestions seem quite plausible, as I discuss further below. See Carter, "Resemblance and Representation: Towards a New Aesthetic in the Music of Monteverdi," in Con che soavità: Studies in Italian Opera, Song, and Dance, I580-I 740, eds. Iain Fenlon and Tim Carter (Oxford: Clarendon Press, 1995), 120. 
rapid and urgent figurations, joyful and dancing, until I was close to becoming overwhelmed with the violence of my mood . . . excited by thoughts of combat and battle. And finally, with a slackened impulse, I was brought to a calmer frame of mind inclined to compassion, divine love, and denial of worldly things. ${ }^{10}$

In Kircher's description, the instrumental sonata can, simply through its highly capricious and expressive musical language, move not only the emotions of the listeners, but also their imaginations; apparently abstract music has the power to conjure feelings and images that would, in vocal music, be made explicit through text. Paolo Fabbri cites letters and writings by seventeenth-century theorists that attest to the use of the term rappresentare to describe musical portrayals of the "affects of the soul." 11

\section{Music Books as Pedagogical Texts and as Records of Improvisational Practice}

Beginning around 1600 , the musical marketplace was flooded with printed volumes of song for one or more high voices and continuo. Although books of polyphonic canzonas had appeared in Italy towards the end of the sixteenth century, it was not until the 1610 and '2os that volumes of instrumental music with similar textures-that is, for soprano instruments and bass-were first published with any regularity. This is not to say that such music did not exist prior to its printed manifestations; indeed, there is ample evidence to suggest that music of this type-or at least of related types-existed even before the seventeenth century, and that the music books of this period signify a shift from a tradition based on improvisation to one fixed in print. ${ }^{12}$

Examining the prefaces and dedications of songbooks published between 1602 and 1635 , Ellen Rosand has demonstrated that many

10 Translated in Peter Allsop, The Italian "Trio" Sonata From Its Origins Until Corelli, Oxford Monographs on Music (Oxford: Clarendon Press, 1992), 57.

${ }^{11}$ Quoted from a letter by theologian Cherubino Ferrari following the performance of Monteverdi's Orfeo in 1607. See Paolo Fabbri, Monteverdi, trans. Tim Carter (Cambridge: Cambridge University Press, 1994), 76. Primarily following Doni, Fabbri equates the stile rappresentativo with the stile recitativo. See ibid., 164-8.

12 On vocal monody in the sixteenth century, see, for example, Claude Palisca, "Vincenzo Galilei and some Links between 'Pseudo-Monody' and Monody," in Studies in the History of Italian Music and Music Theory (Oxford: Clarendon Press, 1994), 346-63; original publication in The Musical Quarterly 46, no. 3 (July 1960): 344-6o. On an instrumental repertoire that prefigured the printed music of the 1610 s and '2os, see John Walter Hill, "The Emergence of Violin Playing into the Sphere of Art Music in Italy: Compagnie di Suonatori in Brescia during the Sixteenth Century," in Musica franca: Essays in Honor of Frank A. D'Accone, ed. Alyson McLamore, Irene Alm, and Colleen Reardon (Stuyvesant: Pendragon, 1996), 333-66. 
constitute "printed singing lessons," intended to replace the oral transmission of information on vocal performance from professional singerteacher to student. ${ }^{13}$ The extensive introduction to Giulio Caccini's first book of Nuove musiche described in words what other books (including Caccini's second volume) conveyed in notes by recording practices of musical expression and ornamentation that were integral elements of the new style. Whatever else they did, monody books thus served a pedagogical purpose.

The note to the readers of Dario Castello's first book of Sonate concertate in stil moderno (1621) suggests that the same was true of instrumental volumes:

Dear Readers: to give satisfaction to those who may find pleasure in playing these sonatas of mine, I advise them that if on first sight [the sonatas] seem difficult, they nevertheless do not lose spirit through playing them more than once; since with practice they will be more easily played: for nothing is too difficult for one who delights in it; and I say that I could not have made them easier while still using the stile moderno, now used by everyone. ${ }^{14}$

For Castello, part of the significance of the stile moderno lies in learning to play in the manner of a virtuoso. The composer encourages purchasers of his book not to be discouraged if his works appear too difficult, but rather to repeat the passagework that pervades his sonatas until they have perfected it. As a teacher might chide a student, Castello pushes his reader to practice until he masters the stile moderno.

It may be more than mere technical virtuosity that Castello has in mind. The shift from an oral to a printed tradition causes music to become fixed and replicable in a way that was not possible earlier. ${ }^{15}$ It seems possible to discern in this music what Nino Pirrotta called

13 Ellen Rosand, “'Senza necessità del canto dell'autore': Printed Singing Lessons in Seventeenth-Century Italy," in Atti del XIV congresso della Società Internazionale di Musicologia: Trasmissione e recezione delle forme di cultura musicale, Bologna, 1987, vol. 2, Study Sessions, ed. Angelo Pompilio, Donatella Restani, Lorenzo Bianconi, and F. Alberto Gallo (Turin: Edizioni di Torino, 1990), 214-24.

14 “Alli Benigni Lettori: M'è parso, per dar satisfatione à quelli che si deletterano di sonar queste mie sonate, avisarli che se bene nella prima vista li pareranno difficili; tuttavia non si perdino d'animo nel sonarle più d'una volta: per che faranno prattica in esse \& all'hora esse si renderanno facilissime: perché niuna cosa è difficile a quello che si diletta: dechiarandomi non haver potuto componerle più facile per osservar il stil moderno, hora osservato da tutti." Castello, Sonate concertate in stil moderno . . . libro primo (1621), 3 . Translation mine. This note appears in both the first printing of 1621 and in subsequent reprints.

15 On the implications of the shift from orality to literacy, see Walter Ong, Orality and Literacy: The Technologizing of the Word, New Accents, ed. Terence Hawkes (London: Methuen, 1982; London: Routledge, 1991; 2001/R). 
"glimpses of an unwritten tradition" 16 -and indeed, this is true of much of the music of the stile moderno. The virtuosic passagework so essential to both the vocal and instrumental repertoires of this period may capture performance practices that had their origins in improvisation. ${ }^{17}$

Perhaps the most well-known example of printed vocal virtuosity as a record of improvisation is the score of "Possente spirto," from Monteverdi's L'Orfeo, published in 16og. The composer offers two versions-one skeletal and one ornamented in the extreme. In keeping with the descriptive nature of the score as a whole, it is likely that the ornamented version records the song as it was performed at the work's premiere in 1607 , or at least some approximation of that performance. But the ornamented version serves a prescriptive function as well: although this score did not overtly claim to have a pedagogical purpose, its purchasers would be able to use the printed ornaments as a model for their own improvisations, or as a script for performances that pose as improvisations.

Caccini, too, indicates that his written texts are meant to simulate improvised or quasi-improvisatory practices. In Le nuove musiche (1602), which, unlike the score of L'Orfeo, is a self-consciously pedagogical text, Caccini includes pieces from his Il rapimento di Cefalo (1600) with ornaments written out, so that the singer who wishes to perform those works may "concentrate solely on good style and affect." 18 The first solo song from Il rapimento, "Muove si dolce," bears an introductory note indicating that "This air was sung, with passaggi as given, by Melchior Palontrotti." Before "Caduca fiamma," however, Caccini explains that the aria was sung "with different passaggi, according to his own style, by Jacopo Peri." Finally, "Qual trascorrendo" was "sung, with some of the passaggi as given and some according to his own taste, by the famous Francesco Rasi." 19 Taken

16 Nino Pirrotta, "New Glimpses of an Unwritten Tradition," in Music and Culture in Italy from the Middle Ages to the Baroque: A Collection of Essays (Cambridge, MA.: Harvard University Press, 1984), 51-71; original publication in Words and Music: The Scholar's View: A Medley of Problems and Solutions Compiled in Honor of A. Tillman Merritt, ed. Laurence Berman (Cambridge, MA.: 1972), 271-92.

${ }_{17}$ Castello's emphasis on the modernity of his style, "now used by everyone," may signify a desire to lay claim to the invention of that style, a practice not uncommon among composers of the early seventeenth century. Indeed, composers of monody and opera in the first years of the century likewise fought to establish themselves as inventors of a given style. On Caccini's efforts in this regard, see Tim Carter, "Printing the 'New Music," in Music and the Cultures of Print, ed. Kate van Orden (New York: Garland, 20oo), $3-37$.

18 “. . . usare solo la buona maniera, e l'affetto." Giulio Caccini, introductory note to the final chorus of $\mathrm{Il}$ rapimento di Cefalo, in Le nuove musiche (Florence, 1602). Translations by $\mathrm{H}$. Wiley Hitchcock in Giulio Caccini, Le nuove musiche, Recent Researches in the Music of the Baroque Era 9, 2nd ed. (Middleton, WI: A-R Editions, 2009), 47-5o.

19 The rubric before "Muove si dolce" reads "Quest'Aria canto solo con i proprij paßaggi come sta Melchior Palontrotti." The prefatory note to "Caduca fiamma" states, "Quest'aria canto solo con altri passaggi secondo il suo stile Iacopo Peri." The note 
together, these three rubrics explain Caccini's role as a redactor of music. Even in Caccini's own compositions, professional singers would follow his suggestions for ornamental passagework only on some occasions; on others they would ornament according to their own preferences.

Whether Palontrotti, Peri, or Rasi actually improvised their passaggi or worked them out in advance is, in a sense, immaterial; the character of the ornamentation embraces stylistic diversity and a sense of immediacy in its shifts from one character to another. As Caccini explained in the introduction to his second songbook, Le nuove musiche e nuova maniera di scriverle (1614),

It is advisable for him who professes to sing alone well, with expression, to know three things. These are: affect, variety of [affect], and sprezzatura. . . V Variety of affect is that transition from one affect to another, by the same means [mentioned above], the singer being guided by the [changes in the] words and meaning from one moment to another. ${ }^{20}$

By altering the affect of a song "from one moment to another," the singer infuses his music with a rhetoric of invention-a sense that the text and music come to him in the moment of performance. The diverse passaggi contribute to this illusion, allowing the singer a means to vary the affect of the song in extreme ways.

Castello's note, too, indicates that the didactic nature of his printed music_like vocal music_-relates not only to technical prowess, but also to facility with a quasi-improvisatory style. For players still learning the arts of ornamentation and improvisation, printed music offered a prefabricated repertoire that was infused with an air of immediacy and spontaneity; it educated players in the new idiom while also building their confidence, perhaps with the expectation that they would one day graduate to truly improvised performances.

The most extreme example of this kind of writing in Castello's oeuvre occurs in the opening sonata of his second volume of Sonate concertate in stil moderno (1629). Like all of Castello's sonatas, the work opens with a point of imitation and a variant of the dactylic rhythm common

before "Qual trascorrendo" reads "Quest'aria canto solo parte con i propri passaggi, e parte à suo gusto il famoso Francesco Rasi Nobile Aretino."

20 "Tre cose principalmente si convengon sapere da Chi professa di ben cantar con affetto solo. Ciò sono lo affetto, la varietà di quello, e la sprezzatura. . . . La varietà nell'affetto è quel trapasso che si fa da uno affetto in un'altro co'medesimi mezzi, secondo che le parole e'l concetto guidano il cantante successivamente." Caccini, introduction to Le nuove musiche, e nuova maniera di scriverle (Florence: Pignoni, 1614). Transcribed in Gaetano Gaspari, Catalogo della biblioteca del Liceo Musicale di Bologna (Bologna: Libreria Romagnoli dall'Acqua, 1893), vol. 3, 294. Translation by H. Wiley Hitchcock in Giulio Caccini, Nuove musiche e nuova maniera di scriverle (I6I4), Recent Researches in the Music of the Baroque Era 28 (Middleton, WI: A-R Editions, 1978), [xxxiii]. 
EXAMPle 1a. Opening of Dario Castello, "Sonata prima a sopran solo" from Sonate concertate in stil moderno, libro secondo (Venice, 1629), mm. 1-6
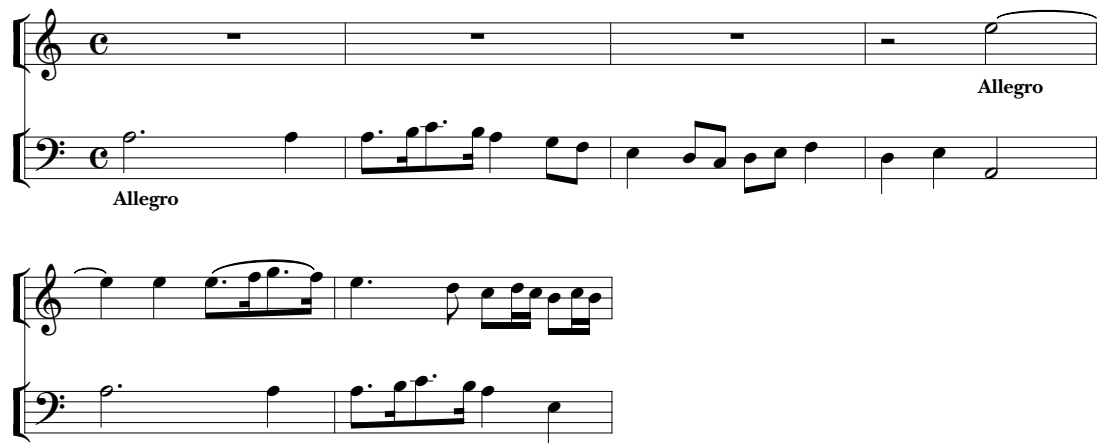

EXAMPLE 1b. Excerpt from Castello, "Sonata prima a sopran solo," mm. 16-18

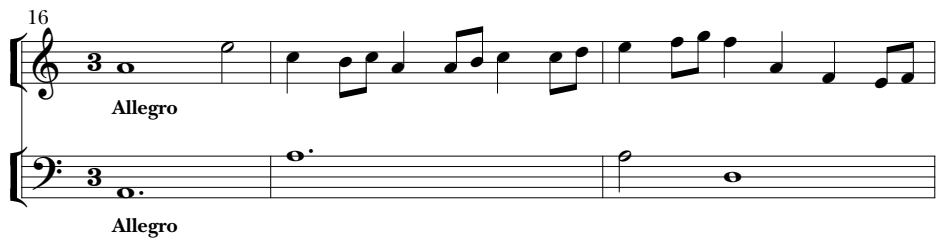

to the late-Renaissance instrumental canzona (see ex. 1a). ${ }^{21}$ As in many canzonas, various sections of the work are unified by common melodic material. Yet Castello's sonata diverges from the standard canzona repertoire both in its scoring and in its occasional incorporation of virtuosic, rhapsodic passagework. Like the ornamented version of "Possente spirto," Castello's "Sonata prima a sopran solo" (that is, for one soprano instrument and continuo) weaves complex filigree around a more basic framework, sometimes incorporating sequences and other repetitive figures, and sometimes introducing new material on a moment-bymoment basis. In this music, contrast is essential; the controlled artifice of contrapuntal imitation, triple-meter dance-like rhythms (see ex. 1b),

${ }^{21}$ On formal conventions in the music of Castello, see Dell'Antonio's chapter on Castello in Syntax, Form, and Genre, 23-64. Although the generic designations "sonata" and "canzona" were sometimes used interchangeably, Eleanor Selfridge-Field has suggested a number of criteria that distinguish the two genres, especially in music composed before 163o. See Eleanor Selfridge-Field, "Instrumentation and Genre in Italian Music, 1600-1670," Early Music 19, no. 1 (February 1991): 61-7. Examples 1a-d are based on the modern edition by Rainer and Hofstötter (see fn. 6). 
EXAMPLE 1c. Excerpt from Castello, "Sonata prima a sopran solo," mm. $5^{1-54}$

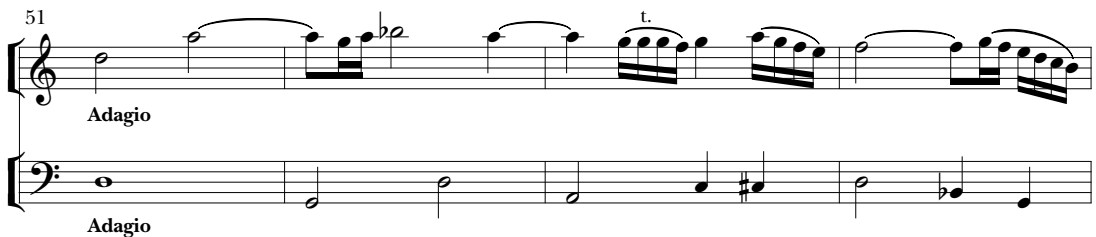

EXAMPle 1d. Excerpt from Castello, "Sonata prima a sopran solo," mm. $117-120$
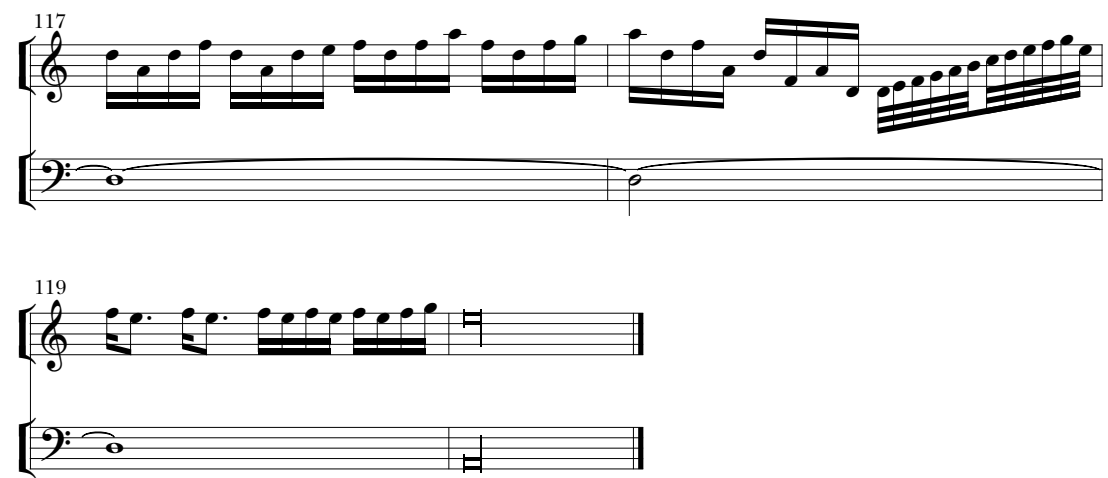

plaintive dissonances (see ex. 1c), and rhapsodic passagework in free meters (see ex. 1d) offered stile-moderno composers a variety of resources to draw upon. ${ }^{22}$ Although Castello's compositional materials derive from a relatively predictable pool, his juxtaposition of opposing gestures lends the music a posture of immediacy, one that may be taken to represent the working-out of musical ideas.

The pedagogical purpose of Castello's printed music, made explicit in the note to the readers of his first collection, thus comes into sharper focus. The extensive ornamentation so characteristic of his music relates to the highly ornamented style that pervades vocal music in the early seventeenth century. In some cases, such as in "Possente spirto," this florid style serves as a record of professional musicians'

22 The contrasts inherent in the music of Castello and others constitute elements of the concerted style, explained in Lorenzo Bianconi, Music in the Seventeenth Century, trans. David Bryant (Cambridge: Cambridge University Press, 1987), 33-6. 
improvisational practice; in others, it allows a composed musical work to assume an air of spontaneity. Through its virtuosity and its apparently capricious, at times wild exploration of the affetti, the music of the stile moderno employs a rhetoric of immediacy, enacting the process of musical invention.

\section{Metrical Flexibility and Musical Expressivity}

Doni was not alone in proposing an analogy between instruments and the human voice. One of two 1615 printings of Fresocbaldi's first book of Toccate e partite d'intavolatura di cimablo includes a lengthy preface, in which the composer describes a connection between his toccatas and the contemporaneous madrigal:

Firstly, that this mode of playing should not remain subject to the beat [battuta], [but rather] should follow the manner of modern madrigals, in which any number of difficulties are made easier by carrying the beat now slowly, now quickly, and suspending it in the air according to their affects, or the sense of the words. ${ }^{23}$

This description of the relationship between Frescobaldi's toccata style and the affective expressivity of the madrigal asserts that instrumental music, too, can communicate and arouse the affetti. Frescobaldi's explanation of this process of communication is, like Doni's, tantalizingly unclear, and perhaps necessarily so. In vocal music, the words determine the underlying affect of a passage of music; in instrumental pieces, the performer's interpretation of the musical notation alone had to suffice to give direction to a work's sonic and emotional realization.

In many types of early seventeenth-century music - those that approximate improvisation and those that do not-metrical flexibility is an essential tool of musical expressivity. In some cases this flexibility calls for an abandonment of the tactus altogether. Perhaps the most obvious manifestation of this free approach to meter is in the vocal stile recitativo, the execution of which depends entirely on the versification and emotional content of the text. According to Jacopo Peri, flexibility

23 "Primieramente: che non dee [sic] questo modo di sonare stare soggetto a battuta, come veggiamo usarsi ne i Madrigali moderni, i quali quantunque difficili si ageuolano per mezzo della battuta portandola hor languida, hor veloce, e sostenendola etiandio in aria secondo i loro affetti, o senso delle parole." Girolamo Frescobaldi, Toccate $e$ partite d'intavolatura di cimablo, nuovamente da lui date in luce e con ogni diligenza corrette, libro primo (Rome: Nicolò Borboni, ${ }_{1615}$; facsimile edition, Florence: Studio per Edizioni Scelte, 1980$)$, [i]. 
of meter is an essential element-perhaps the defining component-of recitative:

And I considered that that type of voice assigned to singing by the ancients which they called "diastematic" (as it were, sustained and suspended) could at times speed up and take an intermediate path between the suspended and slow movements of song and the fluent, rapid ones of speech, and thus suit my intention . . . approaching the other [species] of speech, which they called "continuous," and which our moderns (although perhaps for another end) have also done in their music. I realized, similarly, that in our speech some words are intoned in such a manner that harmony can be founded upon them, and that while speaking one passes through many other [words] which are not intoned, until one returns to another that can move to a new consonance. And taking note of these manners and those accents that serve us in grief, joy, and in similar states, I made the bass move in time to these, now faster, now slower, according to the emotions . . . ${ }^{24}$

Frescobaldi's toccatas thus provide an instrumental cognate for Peri's recitative. Frescobaldi's preface quoted above indicates that his toccatas, like the contemporaneous madrigal, are to be liberated from a governing battuta. It is this freedom, or perhaps the contrast between the free sections and the more measured sections (most notably, those that incorporate contrapuntal imitation), that enables instrumental music to communicate its affective content.

Frescobaldi's description of the beat in modern madrigals — "hor languida, hor veloce, e sostenendola etiandio in aria secondo i loro affetti" (now slowly, now quickly, and suspending it in the air according to their affects) - is reminiscent of Peri's description of the bass line in his newly invented recitative ("feci muovere il basso al tempo di quegli, hor più, hor meno, secondo gli affetti" [I made the bass move in time to these, now faster, now slower, according to the emotions]). ${ }^{25}$ In

24 "E considerai, che quella sorte di voce, che dagli Antichi al cantare fu assegnata, la quale essi chiamavano Diastematica (quasi trattenuta, e sospesa) poteße in parte affrettarsi, e prender temperato corso tra i movimenti del canto sospesi, e lenti, e quegli della favella spediti, e veloci, \& accomodarsi al proposito mio . . . avvicinandosi all'altra del ragionare, la quale continuata appellavano; Il che i nostri moderni (benchè forse ad altro fine) hanno ancor fatto nelle musiche loro. Conobbi parimente nel nostro parlare alcune voci, intonarsi in guisa, che vi si puo fondare armonia, e nel corso della favella passarsi per alter molte, che non s'intuonano, finchè si ritorni ad altra capace di movimento di nuova consonanza. \& havuto riguardo a que' modi, \& a quegli accenti, che nel dolerci, nel rallegrarci, \& in somiglianti cose ci servono, feci muovere il Baßo al tempo di quegli, hor più, hor meno, secondo gli affetti . . ." Jacopo Peri, preface to Le musiche sopra l'Euridice (Florence, 1600), trans. in Margaret Murata, ed., Strunk's Source Readings in Music History: The Baroque Era, Leo Treitler, General Editor (New York: W.W. Norton \& Company, 1998), 659-6o.

25 Ibid., italics mine. 
Frescobaldi's toccatas, the abandonment of the tactus takes place at transitional moments: after a section of measured imitation, for example, the music may give way to virtuosic scales or other passagework. Thus musical material of entirely different characters is juxtaposed, giving the work the variety and sense of spontaneity so essential to the stile moderno.

In the transitional seams of the toccatas the performer's taste and creativity serve as guides, since the notation can only suggest the inherent flexibility of the music (described in Frescobaldi's introduction). As the composer implies, the absence of words in instrumental music requires the performer to convey the affetti through purely musical gestures.

In 1640 the French traveler André Maugars described the relationship between Frescobaldi's toccatas and the composer's own improvisations: "Although [his] printed works give sufficient witness of his ability, in order to judge his profound knowledge it is necessary to hear him improvise toccatas full of contrapuntal devices and admirable inventions." ${ }^{26}$ If Maugars is to be believed, Frescobaldi's toccatas recreate the process of musical invention. In the application of the principles of metrical flexibility and rhetorical expressivity, the player joins in the process of musical creation.

In the opening sections especially, which on paper appear to consist merely of blocked chords, the player's partnership with the composer is solidified through the embellishment and interpretation of the skeletal notation. In the preface Frescobaldi asks the performer to play the openings of the toccatas "slowly and arpeggiated," and to repeat notes in chordal sections (both at the beginnings of the toccatas and in similar passages in middle sections) "so as not to leave the instrument empty." He concludes that such practices are to be implemented "as the player likes." ${ }^{27}$

26 “. . . car bien que ses oeuvres imprimées rendent assez de témoignage de sa suffisance, toutefois pour bien juger de sa profond science, il faut l'entendre à l'improviste faire des toccades pleines de recherches et d'inventions admirables." André Maugars, Response faite à un curieux sur le sentiment de la musique d'Italie (Paris: c. 1640), 13, quoted and translated in Frederick Hammond, Girolamo Frescobaldi (Cambridge, MA: Harvard University Press, 1983), 91-2.

${ }_{27}$ "Li cominciamenti delle toccate sieno fatte adagio et arpeggiando: è così nelle ligature, o vero durezze, come anche nel mezzo del opera si batteranno insieme, per non lasciar voto l'Istromento; il quale battimento ripiglierassi a beneplacito di chi suona." (The beginning of the toccatas should be played slowly and arpeggiated. In suspensions or [other] dissonances, as well as in the middle of the work, [the notes] should be struck together in order not to leave the instrument empty: and this striking may be repeated as the player likes). Frescobaldi, Toccate d'intavolatura . . . libro primo, [i]. Translation in Luigi Ferdinando Tagliavini, "The Art of 'Not Leaving the Instrument Empty': Comments an Early Italian Harpsichord Playing," Early Music 1 1, no. 3 (July 1983): 3oo. 
Metrical freedom is also an essential element in Castello's stile moderno. The "Sonata prima a sopran solo" discussed above is one of the composer's few published works scored for a single soprano instrument and continuo. Playing against a slow-moving bass line and without another melody instrument to enforce its adherence to the tactus, the solo instrument is free to move slowly or quickly, accelerating in a snowballing effect or slowing to highlight dissonances and other expressive features of the composition where such practices are appropriate. Other sonatas by Castello include sections that feature individual instruments as soloists, affording them a similar sense of metrical flexibility.

Biagio Marini's "Sonata variata," published in his Sonate, sinfonie, canzoni, pass'emezzi, baletti, corenti, gagliarde, Ev retornelli, adopts this posture of spontaneity in a manner idiomatic to the violin. In this work the soloist starts with sustained notes on open strings - a significant feature of the composition, since it presents the violinist exploring the most basic sounds of his instrument (or even tuning his strings in preparation for the music that follows); this use of open strings seems analogous to the exploratory chords at the opening of Frescobaldi's toccatas, which offer the player an opportunity to test the temperament of his instrument and warm up his fingers. Marini's violinist seems unsure where to place his fingers; this feature is underscored by the exact repetition of the tentative opening section a fifth lower than the original statement. Repetition in a new mode, though a common feature of late-Renaissance instrumental music, in the stylistic context of this work seems to amplify the instability of the opening section, originating from its willingness to explore a variety of musical avenues on its way to the formation of the sonata.

What follows this opening section appears to have no formal logic. Like the keyboardist performing Frescobaldi's toccatas, Marini's violinist moves erratically from one idea to another, juxtaposing scalar motifs, double-stops over a fast-moving bass line, and triplet passagework. Subdued melodies in the violin's middle range alternate with precariously suspended motifs in the uppermost register of the instrument. The meter alternates frequently between duple and triple, and the pace of the figuration and harmonic rhythm accelerates and slows unpredictably. All registers of the instrument are explored in quick succession, and the affective capacities of the violin are exploited to their fullest. Indeed, the title of the "Sonata variata" captures the essence of a piece that does not consist of variations on any single idea, but rather seems to hinge upon the exploration of a large variety of musical material. The musical language is highly expressive, and, like in Frescobaldi's toccatas, it highlights the relationship between metrical freedom and the quasi-improvisatory idiom of the stile moderno (see ex. 2 ). 
EXAMPle 2. Opening of Marini, "Sonata variata" from Sonate, sinfonie, canzoni, pass'emezzi, baletti, corenti, gagliarde, $\mathcal{E}$ retornelli (Venice, 1626), mm. 23-45
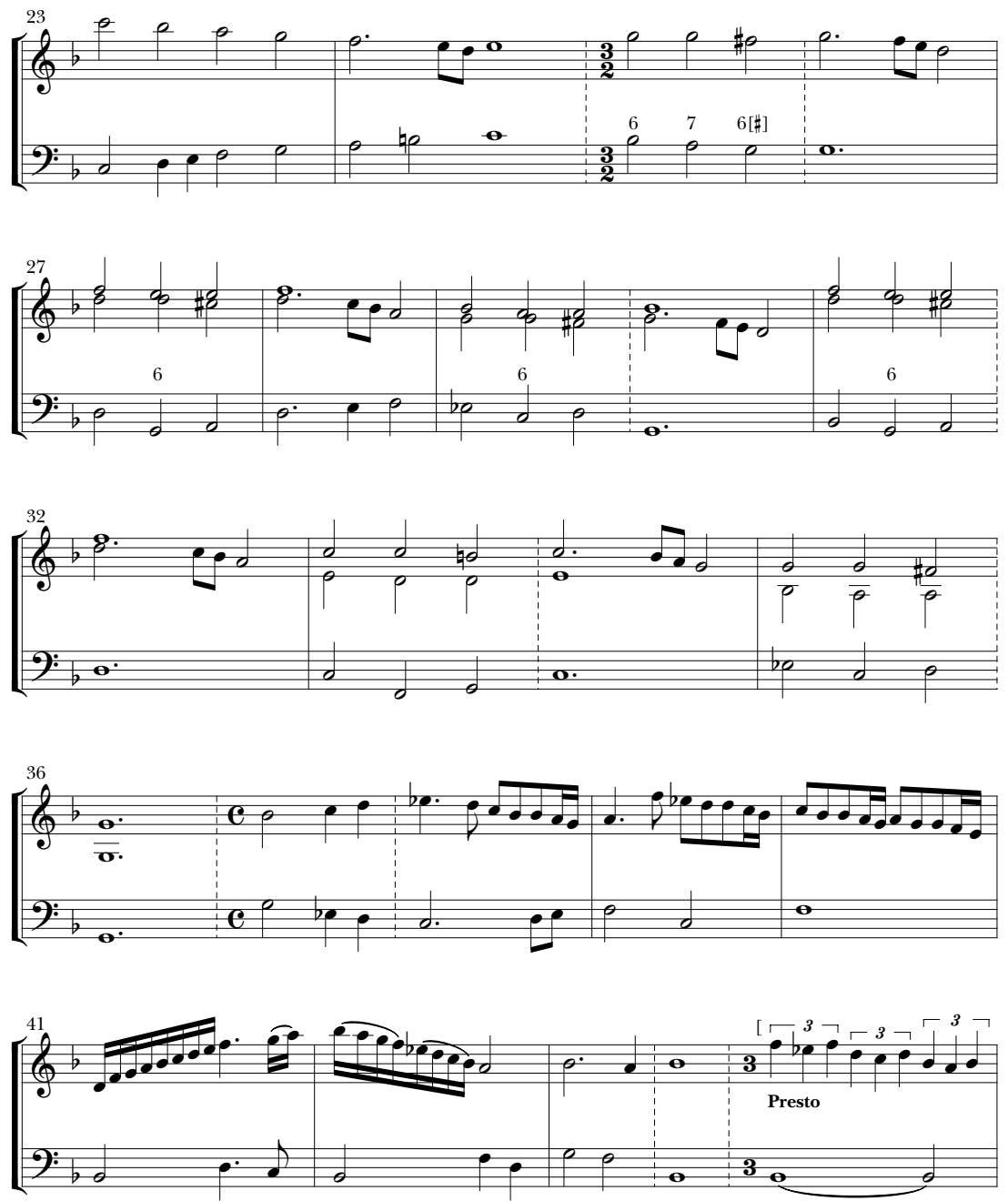

Representation and Metatheatricality in Marini's Sonate, sinfonie, canzoni, pass'emezzi, baletti, corenti, gagliarde, \& retornelli

The metrical flexibility of vocal recitative is associated with a larger project: that of dramatic representation. The speech-like elasticity of recitative is, as Peri points out, governed not only by the versification of 
the poetry, but more significantly by the emotions expressed in the text. The dramatic vocal style hinges on an aura of spontaneity, which allows the singers to simulate the affects of real characters. These emotions are also represented through physical motion on stage, and through the abilities of the singer as an actor.

The first years of the development of opera saw frequent discussion of the relative importance of acting and singing, as well as the need to identify performers who could do both. ${ }^{28}$ For example, in his 1644 description of Anna Renzi, Giulio Strozzi notes that the singer "transforms herself completely into the person she represents." Strozzi describes the staging and physical motions of Renzi's performances as essential means to achieve verisimilar representation:

The action that gives soul, spirit, and existence to things must be governed by the movements of the body, by gestures, by the face and by the voice, now raising it, now lowering it, becoming enraged and immediately becoming calm again; at times speaking hurriedly, at others slowly, moving the body now in one, now in another direction, drawing in the arms, and extending them, laughing and crying, now with little, now with much agitation of the hands. ${ }^{29}$

Strozzi's description does not stop at the visible movements of Renzi's body, but also extends to invisible aspects of her physiology-to the construction of her instrument:

She has a fluent tongue, smooth pronunciation, not affected, not rapid, a full sonorous voice . . . which arises from the temperament of the chest and throat, for which good voice much warmth is needed to expand the passages, and enough humidity to soften it and make it tender. ${ }^{30}$

Composers and theorists of instrumental music also concerned themselves with the physical aspects of performance, the material makeup of

${ }^{28}$ See Ellen Rosand, Opera in Seventeenth-Century Venice: The Creation of a Genre (Berkeley: University of California Press, 1991; 2007/R), 243-4.

29 "L'azzione con quale si dà l'anima, lo spirito, e l'essere alle cose, deve esser governata dal movimento del corpo, dal gesto, dal volto, e dalla voce, hora innalzandola, hora abbassandola, sdegnandosi, \& tornando subito a pacificarsi: una volta parlando in fretta, un'altra adagio, movendo il corpo hor a questa, hor a quella parte, raccogliendo le braccia, e distendendole, ridendo, e piangendo, hor con poca, hora con molta agitatione di mani." Giulio Strozzi, Le glorie della signora Anna Renzi romana (Venice: Surian, 1644). Quoted in Italian in Rosand, Opera in Seventeenth-Century Venice, 428; in English translation ibid., 232.

$3^{0}$ "Hà una lingua sciolta, una pronuntia suave, non affettata, non presta, una voce piena, sonora ... il che nasce dal temperamento del petto, e della gola, per la qual buona voce si ricerca molto caldi, che allarghi le vie, e tanto humido, che le intenerisca, e mollifichi." Ibid. 
their instruments, the role of instrumentalists as actors, and the communication between players and audiences. Their attention to these considerations, many of which were analogous to vocal performance in staged operas, suggests that they may have conceived of this repertoire in some respects as theatrical or dramatic —-similar, perhaps, to the vocal stile rappresentativo. Although instrumental music of this period did not convey programs or tell a story with the same specificity as vocal music, it frequently engaged in imitation and games of role-play, and sometimes even directed performers through explicit staging. Perhaps most important, it introduced audiences to a new protagonist: the instrumental virtuoso.

Castello's note to the reader highlights the importance of physical motion in the virtuosic stile moderno. Through repetitive practice, performers of his music would create and recreate both sound and motion, ignoring, as Castello writes in Sonate concertate in stile moderno, the "difficulties" of the music as they "delight" in it. Castello's nod towards the physical virtuosity of the performer is complemented in Doni's Annotazioni. In addition to comparing the violin and the voice, Doni describes the construction of the instrument and underscores the sharp contrast between its material aspects (especially its small size) and the great diversity of its sonic capabilities. His mention of the "adept hand" that executes the ornaments and passagework of the stile moderno resonates with Strozzi's description of Renzi's vocal physiology.

Doni's comparison suggests that, as in the case of Renzi, virtuosity is put in service of the larger project of dramatic representation. The violin, he claims, has the capacity to imitate the sounds of many other instruments, and, like a singer-actor who can assume the emotional state of a character, the virtuoso can use his violin to convey the affects associated with those instruments:

In sum it represents [rappresenta], when it is in the hand of an adept player, the sweetness of the lute, the suavity of the viol, the majesty of the harp, the vehemence of the trumpet, the vivacity of the fife, the softness of the flute, the pathos of the cornetto; and practically every variety, as in the great machinery of the organ, is heard with marvelous artistry. ${ }^{11}$

31 "In soma egli rappresenta, quando è in mano d'un perito sonatore, la dolcezza del liuto, la soavità della viola, la maestà dell'arpa, la veemenza della tromba, la vivacità del piffero, il querulo del flauto, il patetico del cornetto; \& quasi ogni varietà, che nella gran machina dell'organo, con mirabil'artifizio si sente." Doni, Annotazioni, 338. Translation mine. Even the syntax of this passage seems to foreshadow Strozzi's description of Renzi: "In sum, she transforms herself completely into the person she represents, and seems now a Thalia full of comic gaiety, now a Melpomene rich in tragic majesty." (In soma ella si trasforma tutta nella persona che rappresenta, e sembra hora una Talia piena di comica allegrezza, hora una Melpomone ricca di Tragica Maestà.) Quoted in Italian in Rosand, Opera in Seventeenth-Century Venice, 429; in English translation ibid., $23^{2}$ 
This excerpt highlights the representational potential of instrumental music and the instrumentalist's ability to act. In some cases, merely through its highly expressive sound, the violin could serve as a prop in a dramatic enterprise, offering sonic representation of a host of other instruments. Yet instrumental composers took this theatricality even further, calling on the violinist to employ his virtuosic technique to capture the sounds of multiple violins or other instruments.

The material and theatrical aspects of instrumental performance figure prominently in Marini's Sonate, sinfonie, canzoni, pass'emezzi, baletti, corenti, gagliarde, E् retornelli. The volume's title page advertises "A capriccio in which two violins play four parts. An echo for three violins, and a few capricious sonatas in which a single violin plays two or three parts, with other curious and modern inventions." ${ }^{2}$ These curiose e moderne inventioni push the limits of violin technique, but they also serve a larger purpose: the moments of greatest virtuosity often overlap with points of theatricality (see fig. 1).33

Marini's curiose e moderne inventioni, examples of which will be examined below, are not just bound up with the act of performance. Many of the techniques to which Marini refers are "metatheatrical"- that is, they are self-consciously dramatic, helping to break down the fourth wall that separates the performer from the listener.34 In instrumental music the acts of performance and role-play (facilitated by the curiose e moderne inventioni) are intensely reflexive and self-conscious. Marini's inventioni are techniques that the violinist employs in order to call attention to the processes of performance and mimesis.

Marini's title page does not simply refer to the technical novelties contained in the book, but it also emphasizes the purpose of these novelties, which is to make the violin sound like something else, to imitate an instrument or sound that is somehow out of the ordinary. For instance, in

32 "Un capriccio per sonar due violini quattro parti. Un eco per tre violini, \& alcune sonate capricciose per sonar due e tre parti con il violino solo, con altre curiose \& moderne inventioni."

33 Marini's opus 8 was published in Venice while he was employed at the ducal court of Neuberg, in Bavaria. The musical language of his sonatas is decidedly Italian, although the virtuosic novelties of the curiose e moderne inventioni (like the Inventionen of Carlo Farina, to be discussed below) may reflect the tastes of his German patron. In any case, the publication of Marini's book in Venice demonstrates the composer's (or the patron's) desire that his music enter the Italian public sphere. See Peter Allsop, "Violinistic Virtuosity in the Seventeenth Century: Italian Supremacy or Austro-Hungarian Hegemony?" Saggiatore musicale 3 (1996): 233-58.

34 The foundational text on metatheatricality is Lionel Abel, Metatheatre: A New View of Dramatic Form (New York: Hill and Wang, [1963]); see also Richard Hornby, Drama, Metadrama, and Perception (Lewisburg, PA: Bucknell University Press, 1986). These and subsequent studies on metatheatricality in literature and drama have influenced historical studies of society as performative, including Stephen Greenblatt, Renaissance Self-Fashioning From More to Shakespeare (Chicago: University of Chicago Press, 1980). 
FIgURE 1. Title page of Marini's Sonate, symphonie, canzoni, pass'emezzi, baletti, corenti, gagliarde, E retornelli (Venice, 1626). Reproduced by permission of the University Library, Wroclaw and Studio per Edizioni Scelte

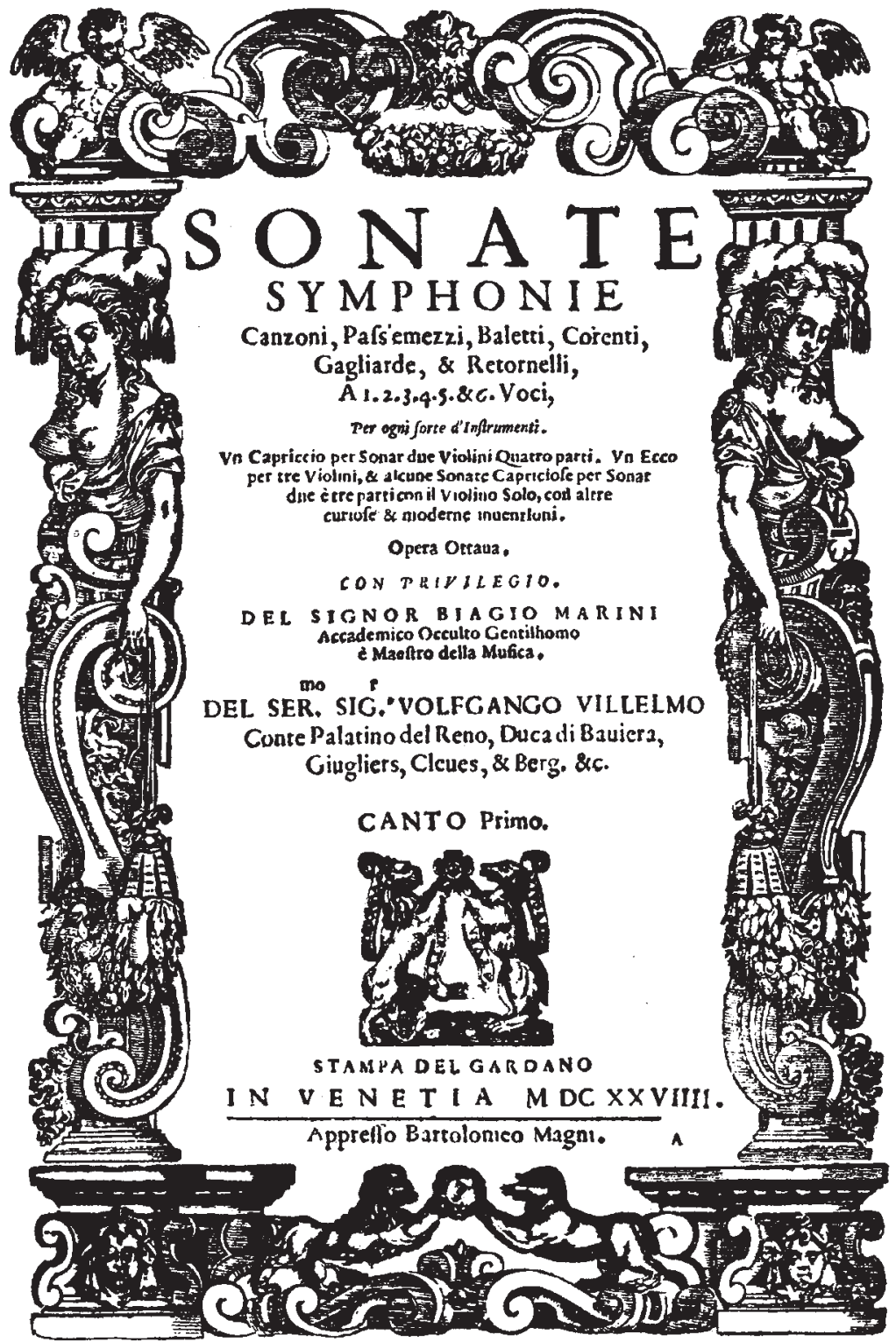


several pieces the violin uses the virtuosic technique of double- or triplestopping to capture the sound of multiple violins or other instruments. To Marini, the violin is thus more than just a producer of sound; it is a device that aids in the composer's project of dramatic display.

One particularly striking example of this can be heard in the "Sonata a 3 in ecco," in which a trio of violins imitates the natural phenomenon of the echo. Approximation of sounds from nature is a common feature in both vocal and instrumental works of the late Renaissance, but Marini's Echo Sonata is also significant because it offers the performers specific instructions for staging, and for interaction with an audience. The canto primo partbook instructs the player: "Questa è la parte che propone forte" (This is the part that sounds loudly). The heading of the violino secondo reads: "Chi sona questa parte non deve esser visto" (Whoever plays this part should not be seen) (see fig. 2). A similar rubric introduces the violino terzo (contained in the basso partbook): "Quello, che suona non deve esser visto." The basso continuo partbook summarizes the configuration of instruments: "Il primo violino deve essere visto, \& gli altri due nò" (the first violin should be seen, but the other two should not).

200 Not seeing the echoing instruments, the audience obviously must be surprised and entertained-overwhelmed, perhaps, by a sense of $m e^{-}$ raviglia - at the sound of the echo emerging mysteriously from an unseen source. Staging is thus an essential component of this piece, and it is employed to enhance the interaction between the player and the audience. Unlike the echo effects in the antiphonal canzonas of Gabrieli, created by placing instrumental choirs of instruments in various locations around a cathedral, Marini's Echo Sonata features a single performer at centerstage. Marini's directions for the staging of the work seem particularly significant: since the echoing instruments "are not to be seen," it seems evident that the principal instrument should be visible, and not hidden in a choir loft. In this respect, the instrumental virtuoso, the only one seen by the audience, may be regarded as analogous to a singer in a staged drama-as a protagonist who displays his virtuosity and artistry.

The virtuosity of the piece reaches its climax in the passage shown in example 3. The first violinist plays double-stops; instead of echoing those literally, the second and third violins divide the notes of the first violin's double-stops between themselves. At the moment when double-stopping is employed, the echo is unmasked: the second and third violins break the relay pattern, highlighting the pretense of the echo effect. ${ }^{35}$ In this metatheatrical moment the performers call the

35 Works that center around the revelation of the artificiality of an echo effect were not uncommon during this period. See, for example, Giovanni Gabrieli's "Canzon in 
FIGURE 2. Second violin part of Marini, "Sonata a 3 in ecco," from Sonate, symphonie, canzoni, pass'emezzi, baletti, corenti, gagliarde, $E^{\circ}$ retornelli. Reproduced by permission of the University Library, Wroclaw and Studio per Edizioni Scelte

Sonata A 3. in Ecco. Violino fec. chi fona queffa parte non deue effer vifto, 26
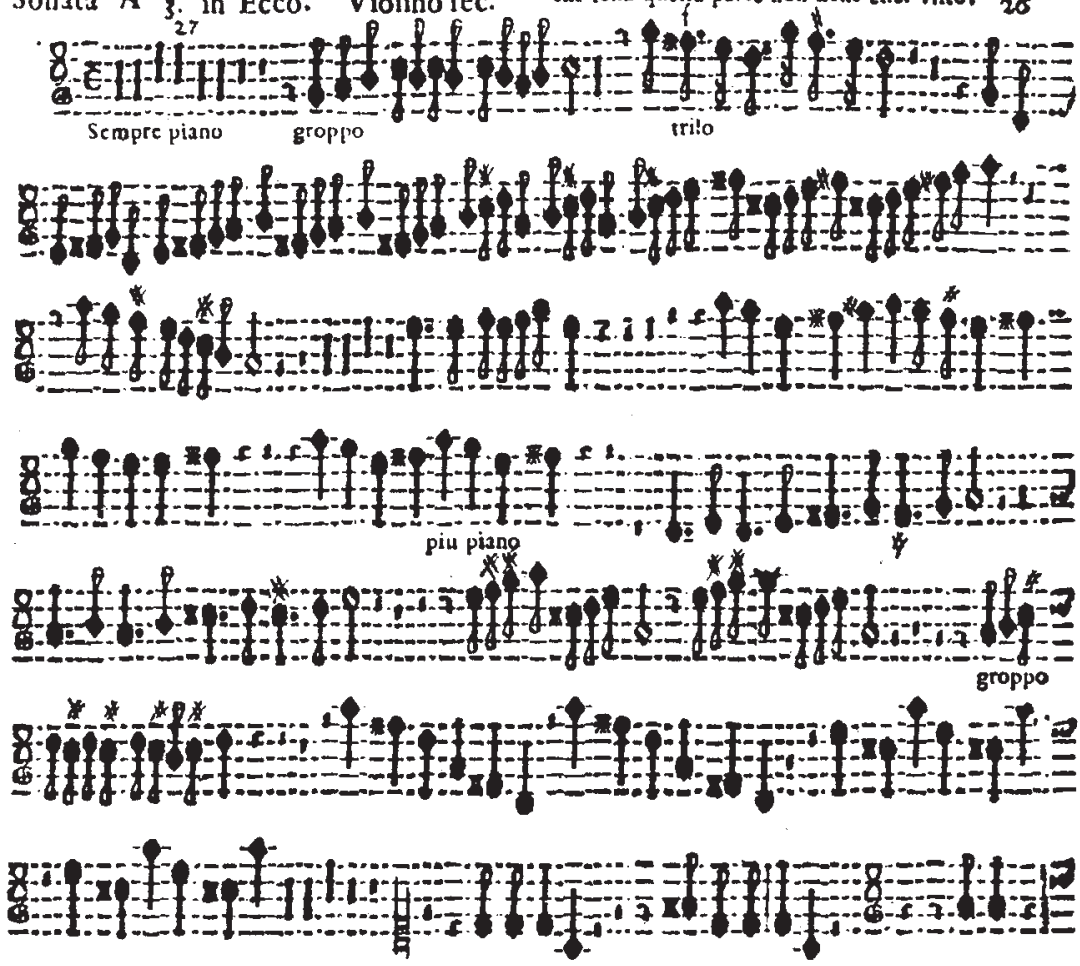
g:a:-

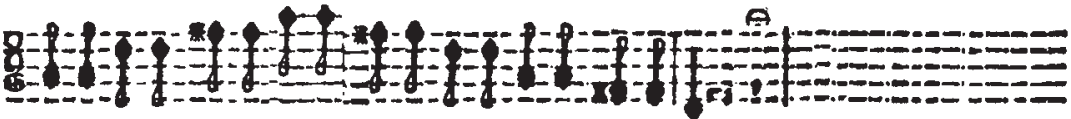

audience's attention to the process of performance, and to the artifice of the music.

echo," C192, unpublished during the composer's lifetime, and edited in Giovanni Gabrieli, Opera omnia, vol. 10, Instrumental Ensemble Works in "Sacrae symphoniae" (Venice, 1597), Printed Anthologies, and Manuscript Sources, ed. Richard Charteris (Neuhausen: HänsslerVerlag, 1998), 192-202. 
THE JOURNAL OF MUSICOLOGY

EXAMPle 3. Excerpt from Marini, "Sonata a 3 in ecco" from Sonate, sinfonie, canzoni, pass'emezzi, baletti, corenti, gagliarde, E' retornelli, mm. $3^{8-44}$
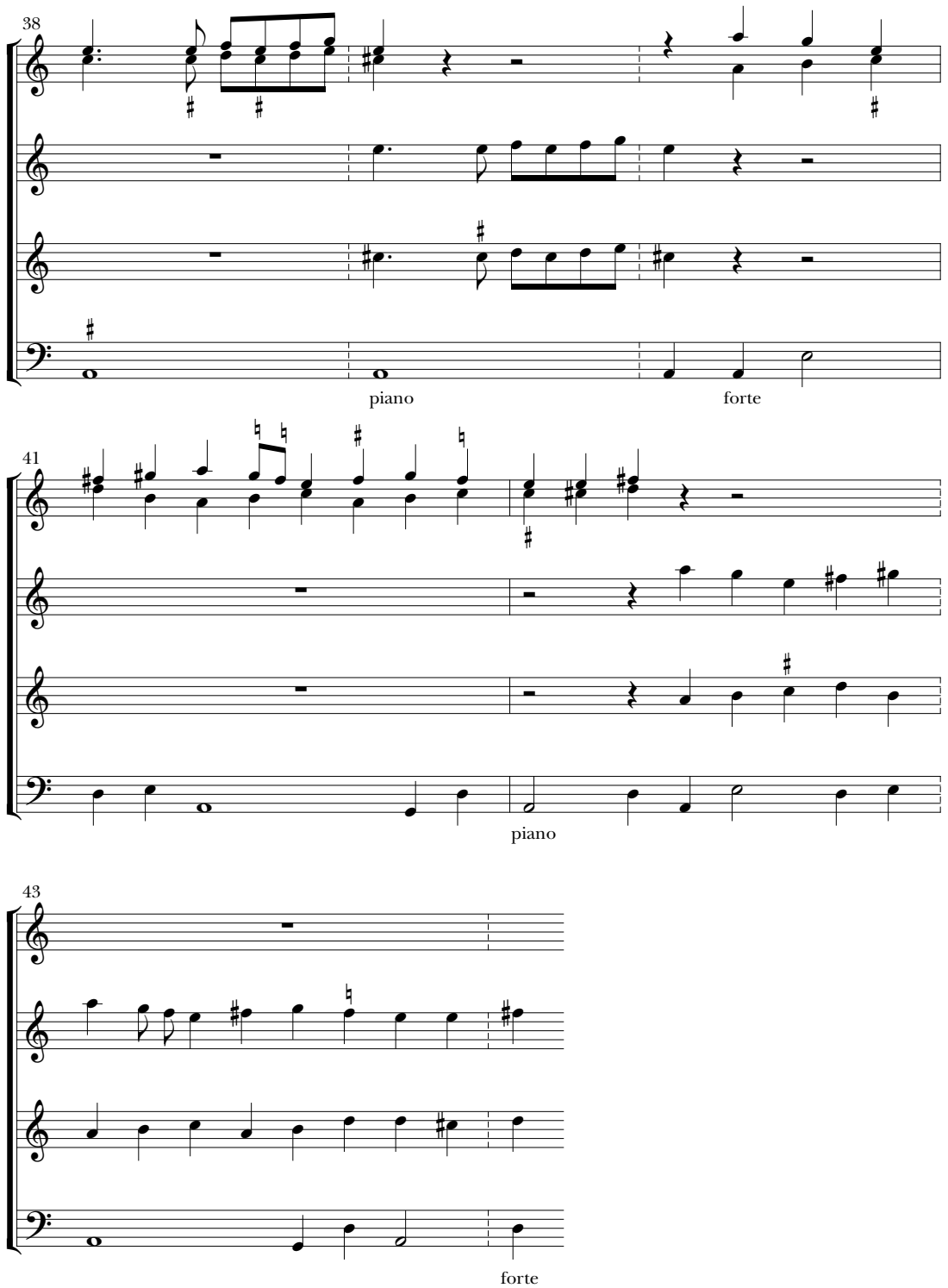
Marini's instructions for staging in the Echo Sonata may be applicable to other pieces in this publication that employ curiose e moderne inventioni. It seems plausible that in such pieces the "inventions," which were intended to inspire a sense of wonder in the audience, would have been put prominently on display in performance..$^{6}$

The "capriccio in which two violins play four parts" would also have inspired a sense of meraviglia, since the audience would have watched as the two violins alternate sections that make use of double-stops in a four-voice quasi-fugal texture, and sections comprised of quick imitative passagework. Though the piece is scored in the modern triosonata texture, the music of the imitative passages poses as an older Renaissance-style canzona. The violins first play the roles of four equal instruments, then of two (see ex. 4). Assuming that the violinists of this piece are meant to be seen by the audience, their imitation of four instruments would easily be understandable as a façade. But this obvious pretense is precisely what gives the music its metatheatrical status. In this work the process of role-play is exposed as a component of the music's theatricality.

Another capriccio in the volume is similarly representational in nature. 37 The "Capriccio per sonare il violino con tre corde à modo di lira" (Capriccio for the violin to play on three strings in the manner of a lira), scored for solo violin and basso, alternates between passages of triple-stopped chords and solo melody. The work imitates the lira da braccio, an instrument in vogue especially during the sixteenth century but in decline by the seventeenth; it was used frequently to accompany the recitation of epic poetry, especially with introductory and intermittent chordal flourishes. $3^{8}$ The opening passage of Marini's Capriccio employs the virtuosic technique of triple-stopping to represent the lira.

$3^{6}$ It seems possible that Marini and Farina employed the term inventioni as it was used in the field of science, in which newly invented tools, instruments, and machines were taken to reflect well on the inventor's patron. Indeed, as Allsop suggests in "Violinistic Virtuosity," the patrons in German courts that hosted Marini and Farina seem to have valued technical novelties in musical performance, perhaps more than Italian patrons of music. If an analogy may indeed be made between scientific inventions and Marini's and Farina's musical inventions, it seems most likely that the performance of the inventioni would have been exhibited prominently - that is, with the performer at center-stage. On the patronage of science see especially Mario Biagioli, Galileo, Courtier: The Practice of Science in the Culture of Absolutism (Chicago: University of Chicago Press, 1993), and Biagioli, Galileo's Instruments of Credit: Telescopes, Images, Secrecy (Chicago: University of Chicago Press, 2006).

37 The fact that both pieces overtly involving role-play are called "capriccio" suggests that Marini connected that genre with mimesis. The mimetic passages of Farina's "Capriccio stravagante," to be addressed further below, support this association.

$3^{8}$ On the music by Marini and Farina in which the violin imitates the lira da braccio, see Rebecca Cypess, "Evidence about the Lira da braccio from Two Seventeenth-Century Violin Sources," Galpin Society Journal 6o (2007): 147-6o. 
THE JOURNAL OF MUSICOLOGY

EXAMPle 4. Opening of Marini, "Capriccio che due violini sonano quatro parti” from Sonate, sinfonie, canzoni, pass'emezzi, baletti, corenti, gagliarde, Ev retornelli, mm. 1-28
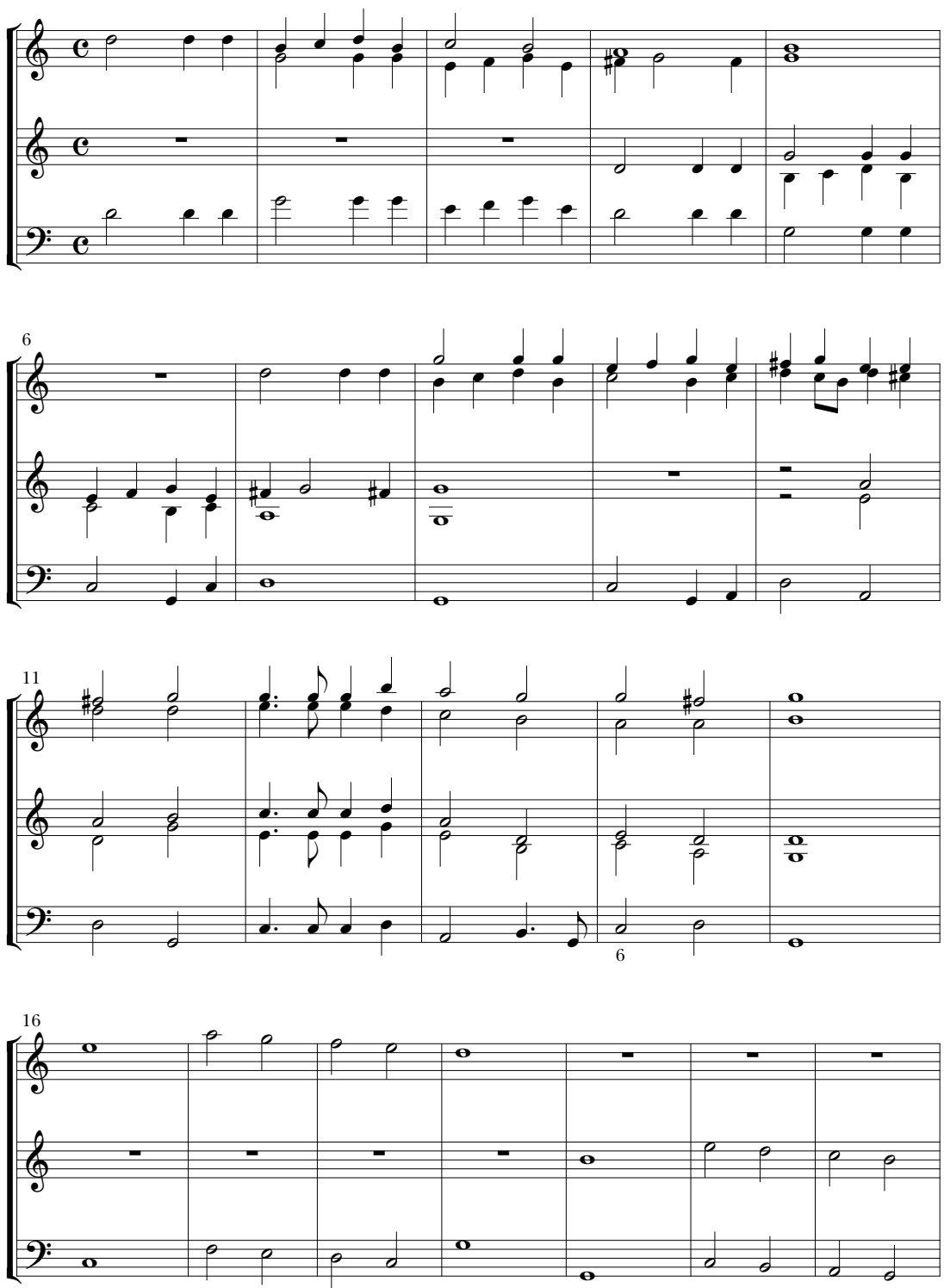
EXAMPLE 4. (continued)
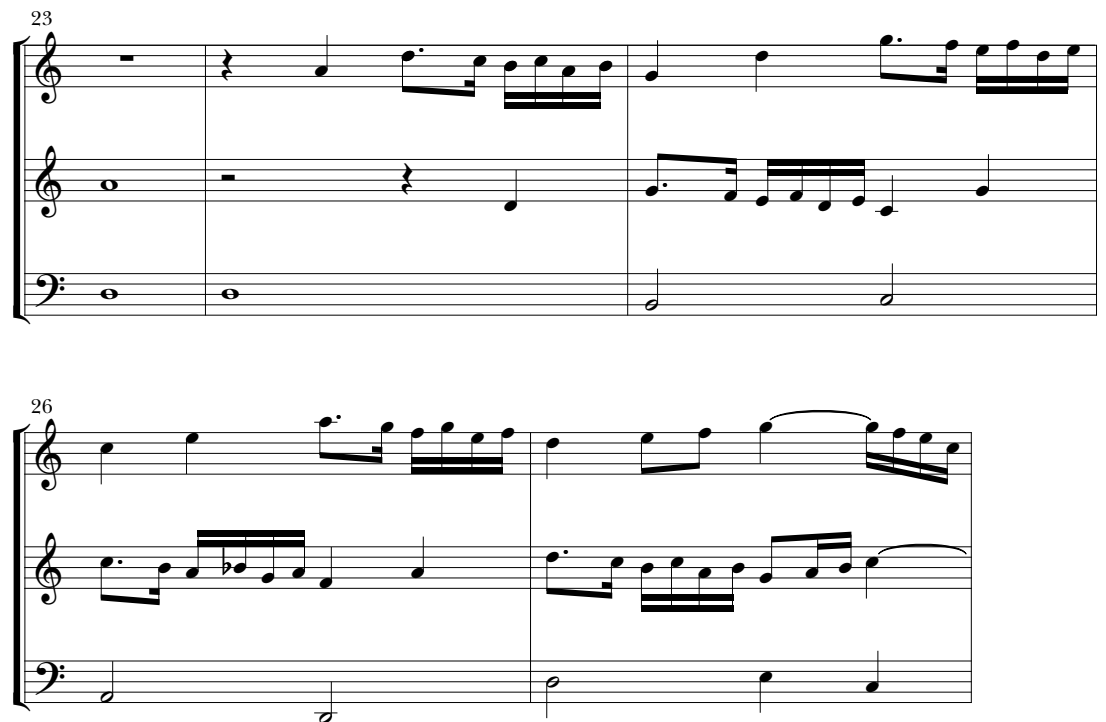

Passages of multiple-stopping alternate with phrases of monodic melody, perhaps meant to imitate the recitation of poetry by a single voice (see ex. 5). The violinist, again engaging in metatheatrical role-play, acts as both accompanist and cantastorie (singer of tales), drawing the audience into his instrumental story-telling. 39

A final example of the metatheatricality of Marini's curiose e moderne inventioni is offered by his "Sonata d'inventione." Midway through the piece a rubric instructs the performer: "Qui si accorda il cantino in terza minore" (Here the cantino [the highest string, or 'little singer'] should be tuned in a minor third [with the next string]); in other words, the violin's E-string should be retuned to C (see fig. 3). The act of tuning an instrument, normally undertaken prior to a performance, might seem unremarkable by itself. In this case, however, Marini calls the audience's attention to a process normally unnoticed or hidden. This composition puts an ordinary action-one required for musical performance but not one usually included in the act of performance itself-on display. The technique of scordatura or "mistuning" becomes

39 Although the meaning of Marini's rubric "Bisogna che le due corde grosse sijno vicine" (The two large [lower?] strings [involved in multiple-stopping] should be placed close together) is not entirely clear, it seems likely that he was instructing the violinist to move the strings closer together to facilitate the performance of triple-stopped chords. 
EXAMPLE 5. Opening of Marini, "Capriccio per sonare il violino con tre corde à modo di lira" from Sonate, sinfonie, canzoni, pass'emezzi, baletti, corenti, gagliarde, Ev retornelli, mm. 1-19
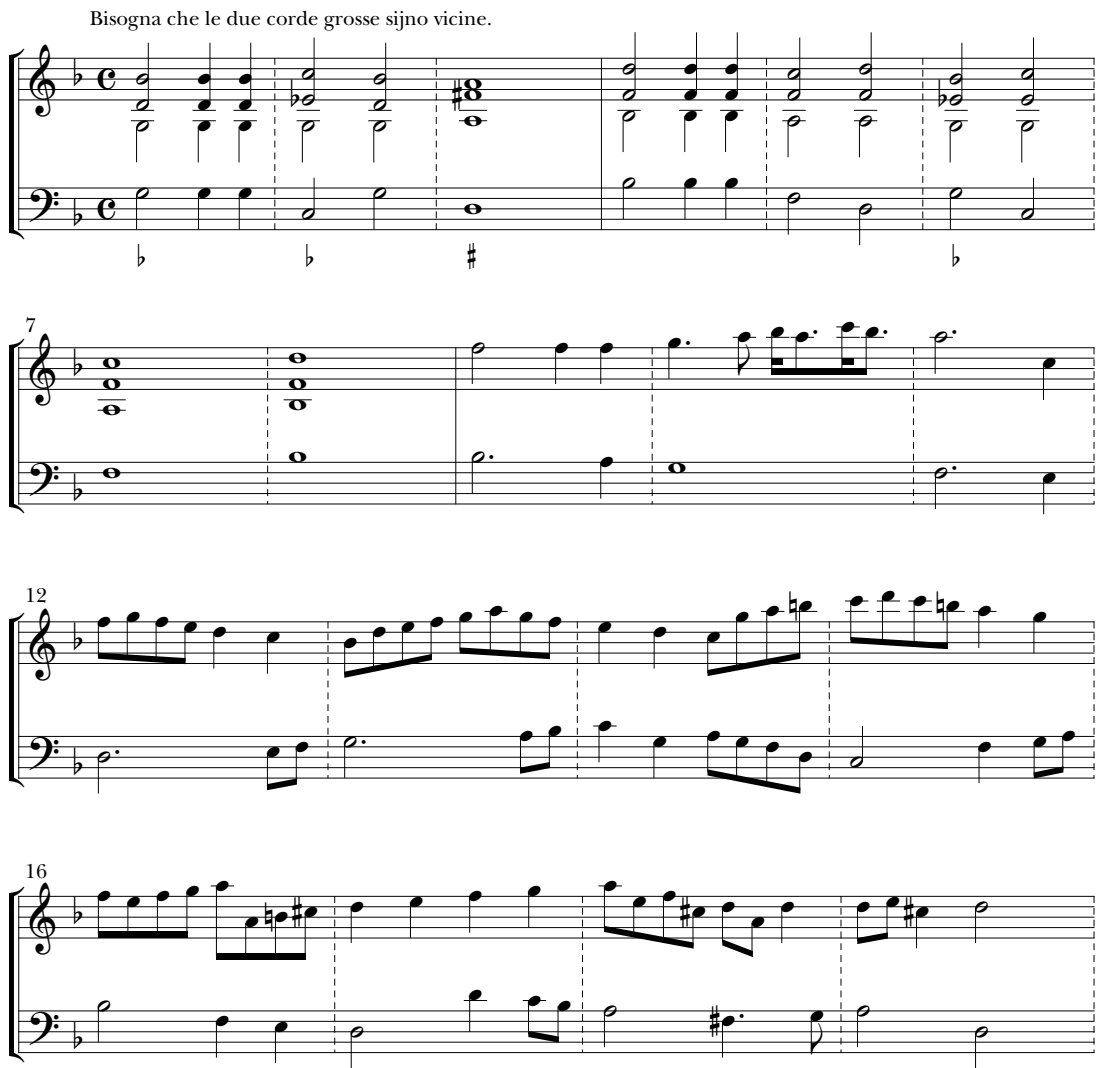

grist for Marini's creative mill, as the instrument is exploited and altered to expand its sonic capabilities.

Representation in Carlo Farina's Capriccio stravagante

Like the title page of Marini's Sonate, sinfonie, canzoni, pass'emezzi, baletti, corenti, gagliarde, Eं retornelli, that of Carlo Farina's Ander Theil newer Paduanen, Gagliarden, Couranten, französischen Arien, benebenst einem kurtzweiligen Quodlibet boasts of the "inventions" found in his book. $4^{\circ}$ These technical

$4^{\circ}$ Carlo Farina, Ander Theil newer Paduanen, Gagliarden, Couranten, französischen Arien, benebenst einem kurtzweiligen Quodlibet von allerhand seltzamen Inventionen, dergleichen vorhin im Druck nie gesehen worden Sampt etlichen Teutschen Täntzen alles auff Violen anmutig zugebrauchen (Dresden: Gimel Bergen, 1627). Modern edition of the Capriccio stravagante in 
FIGURE 3. Opening of Marini, "Sonata seconda per il violino d'inventione," from Sonate, symphonie, canzoni, pass'emezzi, baletti, corenti, gagliarde, Ev retornelli. Reproduced by permission of the University Library, Wroclaw and Studio per Edizioni Scelte

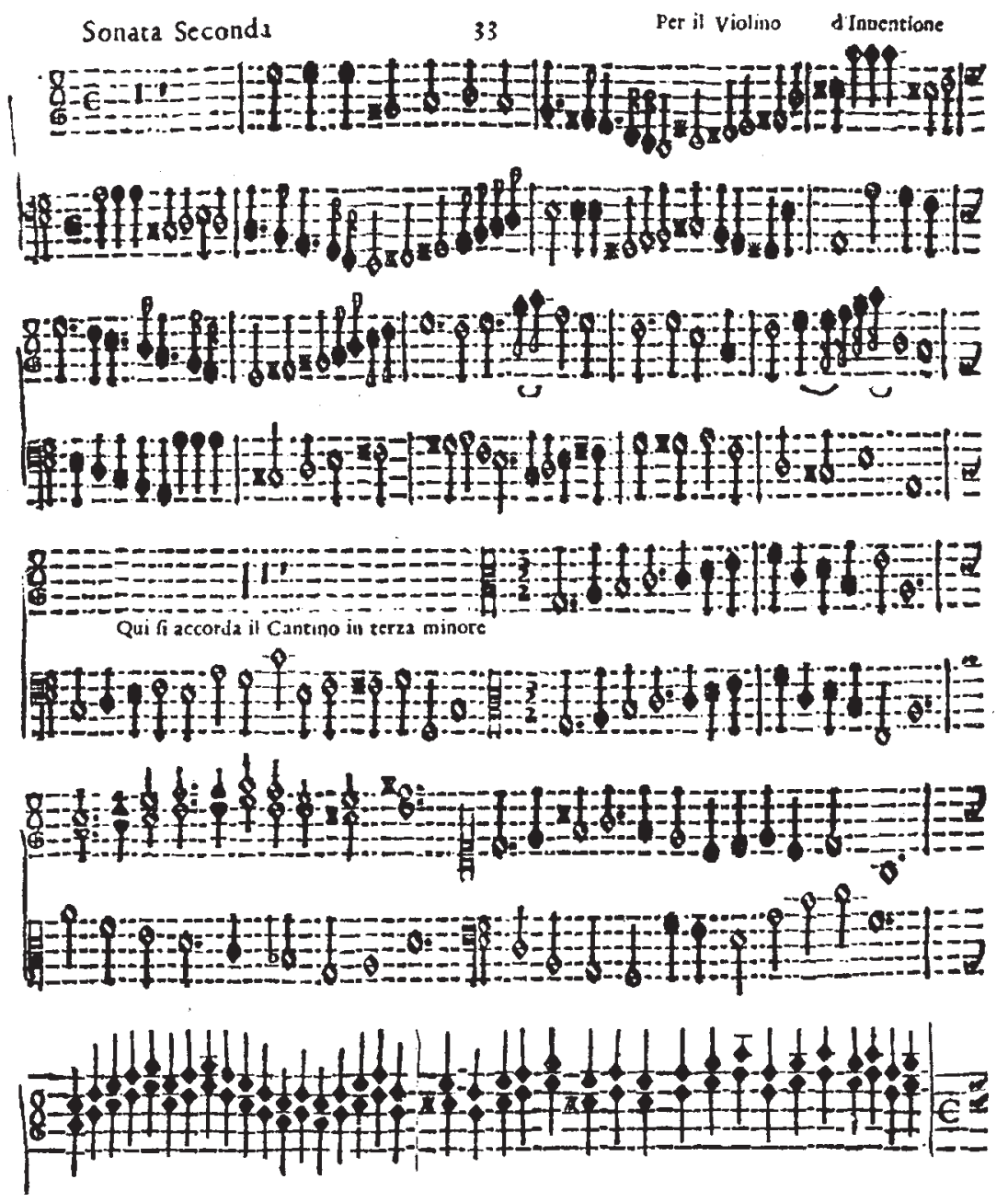

novelties are all displayed in his famed Capriccio stravagante, and, like, the virtuosic tricks in Marini's volume, they contribute to a theatrical mode of instrumental performance. Perhaps to outdo Marini's advertisement of his "curious and modern inventions," Farina declares that the

the new critical edition of Farina's work, Aurelio Bianco, "Nach englischer und frantzösischer Art": Vie et oeuvre de Carlo Farina (Turnhont: Brepols, 2010). 
FIgure 4. Title page of Carlo Farina, Ander Theil newer Paduanen, Gagliarden, Couranten, französischen Arien, benebenst einem kurtzweiligen Quodlibet (Dresden, 1627). Reproduced by permission of the Universitätsbibliothek Kassel, Landesbibliothek und Murhardsche Bibliothek der Stadt Kassel

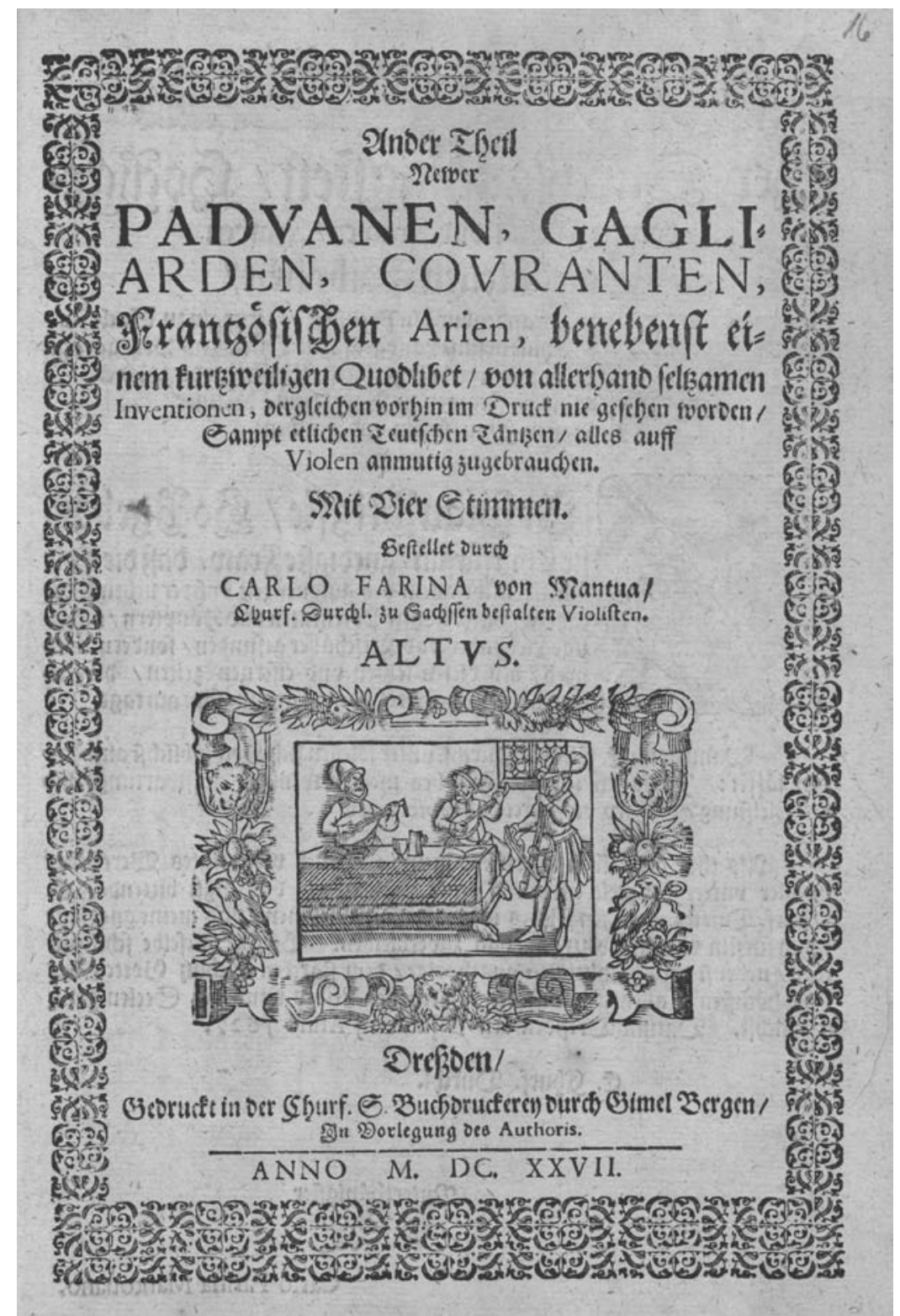


techniques in his work are "Inventionen dergleichen vorhin im Druck nie gesehen worden" (inventions the likes of which have never before been seen in print)..$^{1}$

Like Marini, who published his Sonate while he was employed at the ducal court of Neuberg, Farina was a temporary expatriate. His five books of music were all printed in Dresden between 1626 and 1628, while he was working at the electoral court of Saxony. Most of his published oeuvre consists of dance music for four-part consort, $4^{2}$ and, although many writers exclude Farina from surveys of Italian music because he worked in Germany,43 it is clear that some of Farina's compositions exhibit a distinctly Italian style. The composer's first, fourth, and fifth books contain a total of ten sonatas for one or two violins and continuo; the solo sonatas exhibit traits of the rhapsodic, unpredictable stile

$4^{1}$ The publication date of Marini's opus 8 has long been a subject of scholarly debate. The confusion stems from discrepancies in the surviving sources, summarized in Zoni's modern edition, $x v$ (see note 7 ). The original printed date on the title page $(1625$ in the canto primo; 1626 in the other partbooks) was modified by hand in the only extant exemplar in Wroclaw (PL-WRu) to 1629. This discrepancy led Allsop to suggest that it took Bartolomeo Magni that much time to learn how to produce such a complicated volume, especially to overcome the typographic difficulties related to the printing of double- and triplestops (see Allsop, "Violinistic Virtuosity in the Seventeenth Century," 244). Allsop is no doubt correct that the printing of double-stops was difficult for Magni, but his speculation regarding the publication date seem unconvincing, not least because it does not explain similar modifications to the title pages of Marini's opus 7 and opus 9-both collections of vocal music without double-stops-whose dates were changed from 1624 and 1625 to 1634 and 1635 , respectively, through the written insertion of an extra Roman numeral "X." Ultimately, Allsop and Zoni both conclude that op. 8 was indeed issued in 1629 . However, it seems equally likely, especially given the evidence from opus 7 and opus 9, that the dates of these volumes were modified after their publication to make the music seem more up-todate (or "modern"). Indirect support for the idea that Marini's opus 8 was issued in 1626 may be gleaned from Farina's Ander Theil (1627). Unlike Marini's title page, that of Farina may refer to another book or books that contain "inventions," but claims that his are even more exciting. Despite the fact that Marini's book was published in Venice and Farina's in Dresden, the two may nonetheless have been in competition: at the time of the publication of his Sonate, Marini was employed at the court of Wolfgang Wilhelm of Neuberg, so his publication probably circulated in German- as well as in Italian-speaking areas. It seems possible, therefore, that Farina's title page refers to a competition with Marini, and that his Inventionen were meant to surpass Marini's curiose e moderne inventioni. If so, then Marini's opus 8 must have entered the public domain before the publication of Farina's Ander Theil in 1627 . It is worth noting that the production of double-stops seems to have been as difficult for Farina's printer, Gimel Bergen, as it had been for Magni. In the Kassel (D-Kl) exemplar of the Ander Theil, the lower notes of multiple-stops in the Capriccio stravagante appear to have been added by hand. Another Dresden printer with whom Farina worked, Wolfgang Seiffert, used a different technique: he printed the higher note of the doublestop, and beneath it a number indicating the interval below the top note at which the lower note is to be played. See Farina, Libro delle pavane, gagliarde, brandi, mascherata, aria franzesa, volte, balletti, sonate, canzone (Dresden, Wolfgang Seiffert, 1626).

$4^{2}$ On the influence of the German consort dance on the late seventeenth-century Italian sonata, see John Daverio, "In Search of the Sonata da camera before Corelli," Acta musicologica 57 , no. 2 (1985): 195-214.

43 See ibid., $195^{-8 .}$ 
moderno of Frescobaldi's toccatas and some of Marini's and Castello's sonatas. 44 Although the Ander Theil, the second of Farina's publications, does not contain any sonatas, the Capriccio stravagante embraces the Italianate style through its use of violin virtuosity, which migrated from Italy to German-speaking areas during the early seventeenth century through Italian violinists like Farina, employed by northern patrons. 45 Indeed, the Italian flavor of the Capriccio is evident from Farina's use of Italian rubrics to describe the programmatic content and virtuosic techniques of his composition. Only the basso partbook contains German alongside the Italian rubrics, while the composer's avvertimenti (annotations) concerning the performance of the work include a glossary rendering the Italian terms into German. $4^{6}$

Like Marini's curiose e moderne inventioni, the Inventionen found in Farina's Capriccio have largely been dismissed by modern scholars in pejorative language; William S. Newman, for example, has referred to them as "out-and-out stunts." 47 Yet while the flashy, acrobatic nature of Farina's composition was no doubt meant to impress and entertain, it may, like Marini's inventions, signify more.

Perhaps more than in any other work of the period, the virtuosity 210 displayed in the Capriccio stravagante calls for the instrumentalists to step out of their ordinary roles to become actors. Furthermore, just as Peri calls on singers of his recitative "to imitate in song a person speaking," ${ }^{8}$ Farina invites his performers to imitate even the most ordinary sounds, from folk instruments to barking dogs. Through the use of virtuosic and novel techniques—and a sense of humor — the violin consort stands in for other musical instruments and various creatures, assuming their characters and imitating their noises, even if the results only approximate their models-as recitative did in its imitation of speech.

The first indication that the Capriccio engages in a theatrical project may be seen in the opening and closing sections, which frame the work. The opening portion includes several short dance-like sections. Four phrases in duple meter, each of which is repeated, are followed by a

44 More than the sonatas of Castello and Marini, Farina's solo sonatas employ related thematic material that recurs at various points in a given piece. In many cases, though, these recapitulatory moments vary slightly from one another, giving the impression that the violinist is working from memory or from inspiration in the moment.

45 On the role of Italian violinists in German-speaking areas during this period, see Allsop, "Violinistic Virtuosity." The works of Johann Heinrich Schmelzer (c. 1620/231680), Franz von Biber (1644-1704), and others in the second half of the seventeenth century attest to the Germans' continuing interest in the virtuosic capacities of the violin.

$4^{6}$ My thanks to Aurelio Bianco for referring me to the only surviving copy of the avvertimenti, preserved in the cantus partbook in the Sächsische Landesbibliothek-Staats und Universitätsbibliothek Dresden (D-Dl).

47 William S. Newman, The Sonata in the Baroque Era (New York: Norton, 1983/R), 54.

$4^{8}$ "Imitar col canto chi parla," in Peri's preface to Le musiche sopra l'Euridice (see note 24). 
short segment in 6/4. The duple meter then returns for an extended section involving a dactylic fanfare rhythm exchanged among the instruments (see ex. 6).

The closing section of the Capriccio is entirely different. Following a passage in which the violin imitates the rasgueado (strummed) style of the Spanish guitar, a brief coda begins. Initially in the same tempo as the previous section, the coda gradually slows down, both as a result of Farina's verbal instructions (adagio and sempre più adagio), and because the predominant rhythmic values expand from eighth notes to quarters, then to halves, and finally to a single whole note. The piece does not end on a clear cadence, but rather fades away on an F-major chord, a third away from $\mathrm{D}$, which constitutes the harmonic center of the opening and much of the rest of the piece. But the piece does not end with this F-major haze; instead, Farina closes with a measure of rest-of composed silence (see ex. 7).

While regular meters, dance rhythms, and a repetitive structure make the introduction to the Capriccio seem quite normal and predictable, the disappearing coda seems somewhat bizarre. Together, the introduction and coda set off the work from the other music in the volume, and nearly all other instrumental music of the period. Through the use of this frame Farina hints at a theatrical presentation. In the opening section the fanfare rhythms announce the raising of the curtain; in the final moment of silence the imaginary world of representation is suspended ever so briefly before the inevitable turn to reality. To mediate this boundary Farina invites the noise of the surrounding world to participate in his work. In this instant, the continuous seam between composed music and accidental sound is exposed.

Within the Capriccio there are some thirty-six separate sections, which may be divided into two general categories: those that are illustrative or mimetic and those that are not. The illustrative sections include the "stunts" for which the work has become famous: techniques such as col legno, sul ponticello, and glissando; approximations of the sounds of other instruments (the lira [peasant's lyre or hurdy-gurdy], the pifferino [shawm], the trombetta and clarino [mid-range and high trumpets], the flautino [a high flute or recorder], the tremulant of the organ [a stop that alters the intensity of the air-flow through the organ pipes at a regular rate], the pifferino della soldadesca and tamburo [soldier's fife and drum], and the chittara spagniola [Spanish guitar]);49 and animals (the hen, rooster, dog, and cat). The non-illustrative sections

49 Many of the instruments imitated in Farina's Capriccio are described in Michael Praetorius, Syntagmatis musici: Tomus secundus de organographia (Wolffenbüttel, 1619). English translation in Harold Blumenfeld, The Syntagma musicum of Michael Praetorius: Volume Two. De Organographia, First and Second Parts. Plus All Forty-Two Original Woodcut Illustrations from Theatrum Instrumentorum (New York: Da Capo Press, 1980/R). 
THE JOURNAL OF MUSICOLOGY

EXAMPle 6. Opening of Farina, Capriccio stravagante from Ander Theil newer Paduanen, Gagliarden, Couranten, französischen Arien, benebenst einem kurtzweiligen Quodlibet (Dresden, 1627), mm. $1-14$
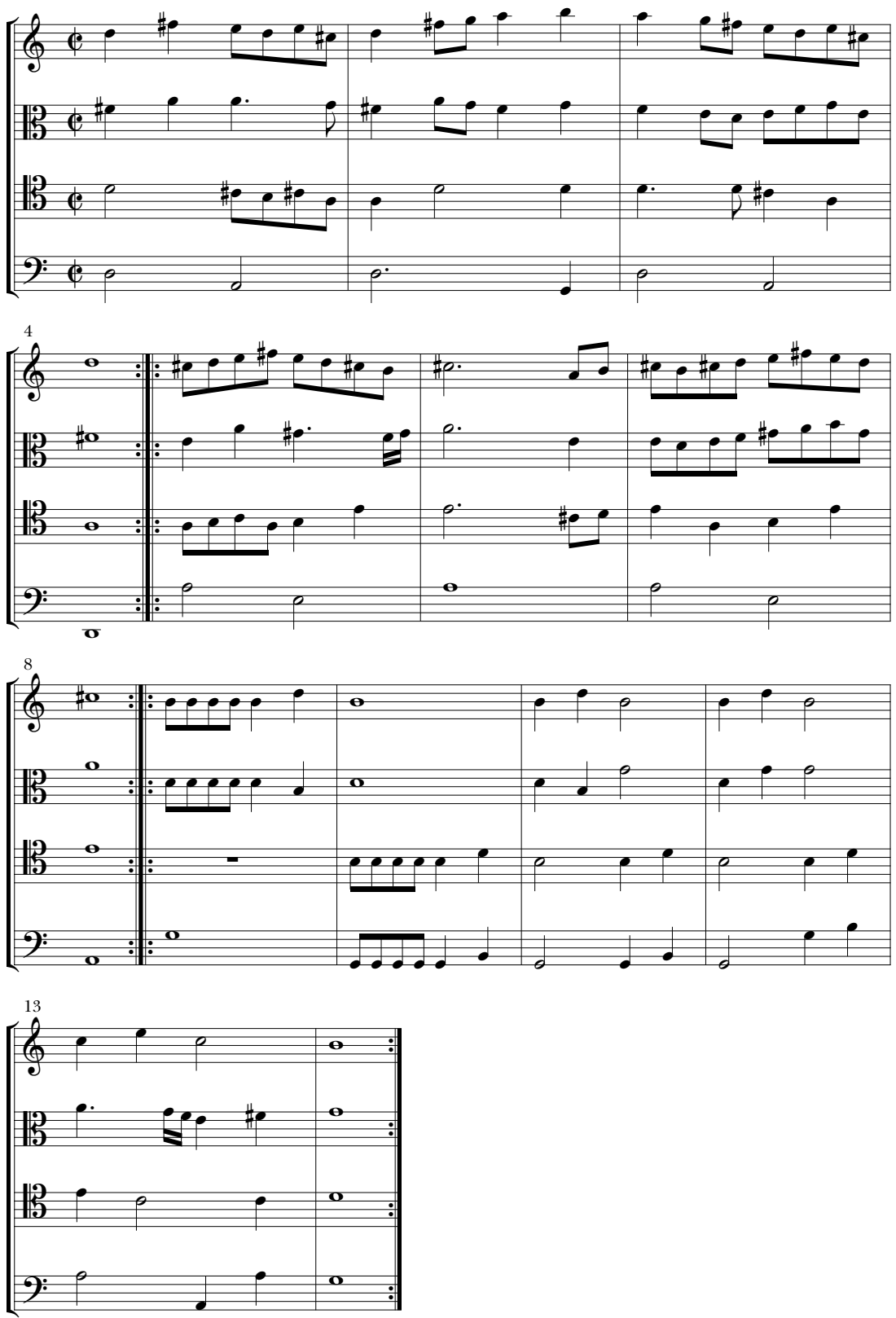
EXAMPLE 7. Closing section of Farina, Capriccio stravagante, mm. 360376
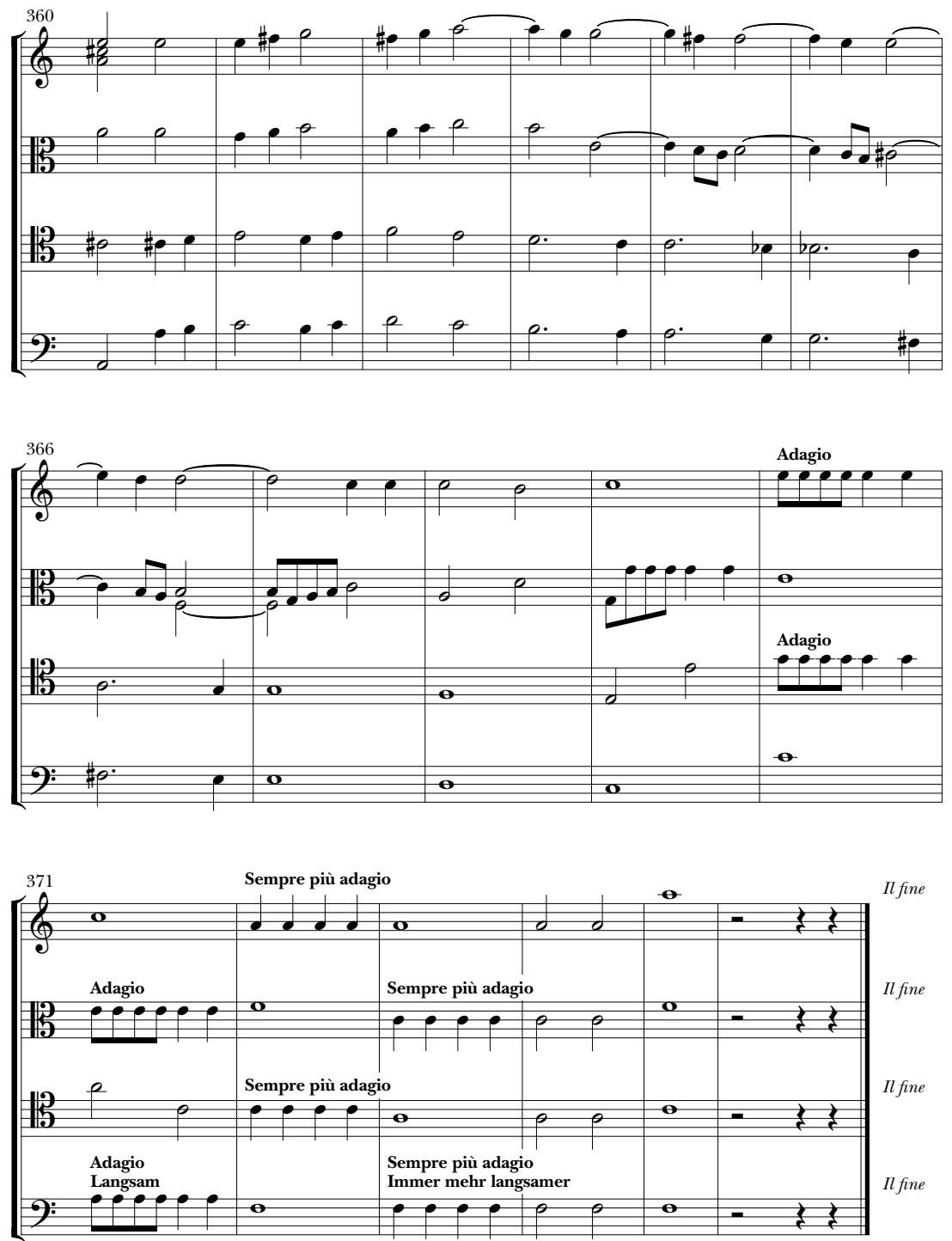
EXAMPLE 8. "Il cane" from Farina, Capriccio stravagante, mm. 307-309

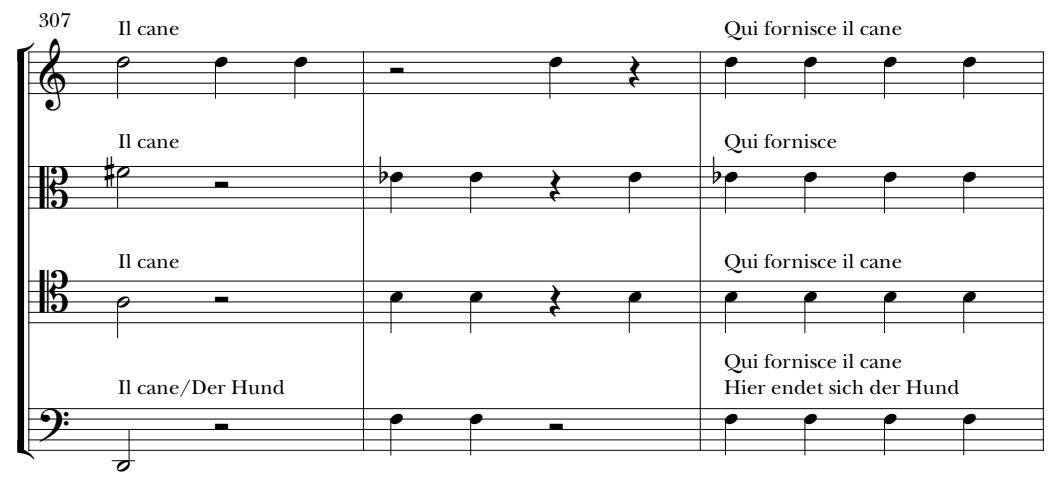

are often overlooked, and perhaps for good reason: most of them do not differ greatly from the dozens of German-style dance pieces that Farina published. Some are in triple meter and some in duple; many of them are built from similar melodic or rhythmic motives. Despite their apparent insignificance, however, these sections are in fact crucial to an interpretation of the work.

Much of the interest in the non-illustrative music of Farina's $\mathrm{Ca}$ priccio lies not in melody but in harmony. Indeed, the melodic material of the Capriccio is quite simple. Whereas the opening measures of the piece are quite singable, other motives-for example, the repeated eighth-note figure that appears in example 6, m. 9-seem designed to serve as background, so as not to call attention to themselves. Musical material of this sort serves as a foil for the more outlandish passages in the Capriccio, functioning as background to the changes of scenes that prepare the next moment of role-play.

By contrast, the harmonic content of the Capriccio is surprising. In some sections the harmony consists of I, IV, and V chords; in others, the harmonies seem uncanny. Some passages containing unusual harmonies support the imitative moments of the piece: the dog's bark, for example, is made up of a group of notes that fall outside the sphere of tonal or modal practice (see ex. 8); the dissonant crow of the rooster includes parallel seconds in the violin (see ex. 9). $5^{\circ}$

$5^{\circ}$ In the depiction of his chickens, Farina initiates a theme that was later taken up almost verbatim by Tarquinio Merula ("La gallina canzon à 2 violini," Canzoni overo sonate concertate per chiesa e camera [Venice: Vincenti, 1637]), Marco Uccellini ("Maritati insieme la gallina e il cukoo fanno un bel concerto," Sonate, arie et correnti [Venice: Vincenti, 1642]), perhaps Jean-Philippe Rameau ("La Poule," Nouvelle suites de pièces de clavecin [Paris: l'Auteur, 1728]) and Franz Joseph Haydn (Symphony no. 83, "La Poule [1 $\left.78_{5}\right]$ ). 
EXAmple 9. "La gallina" and "Il gallo" from Farina, Capriccio stravagante, mm. 180-185
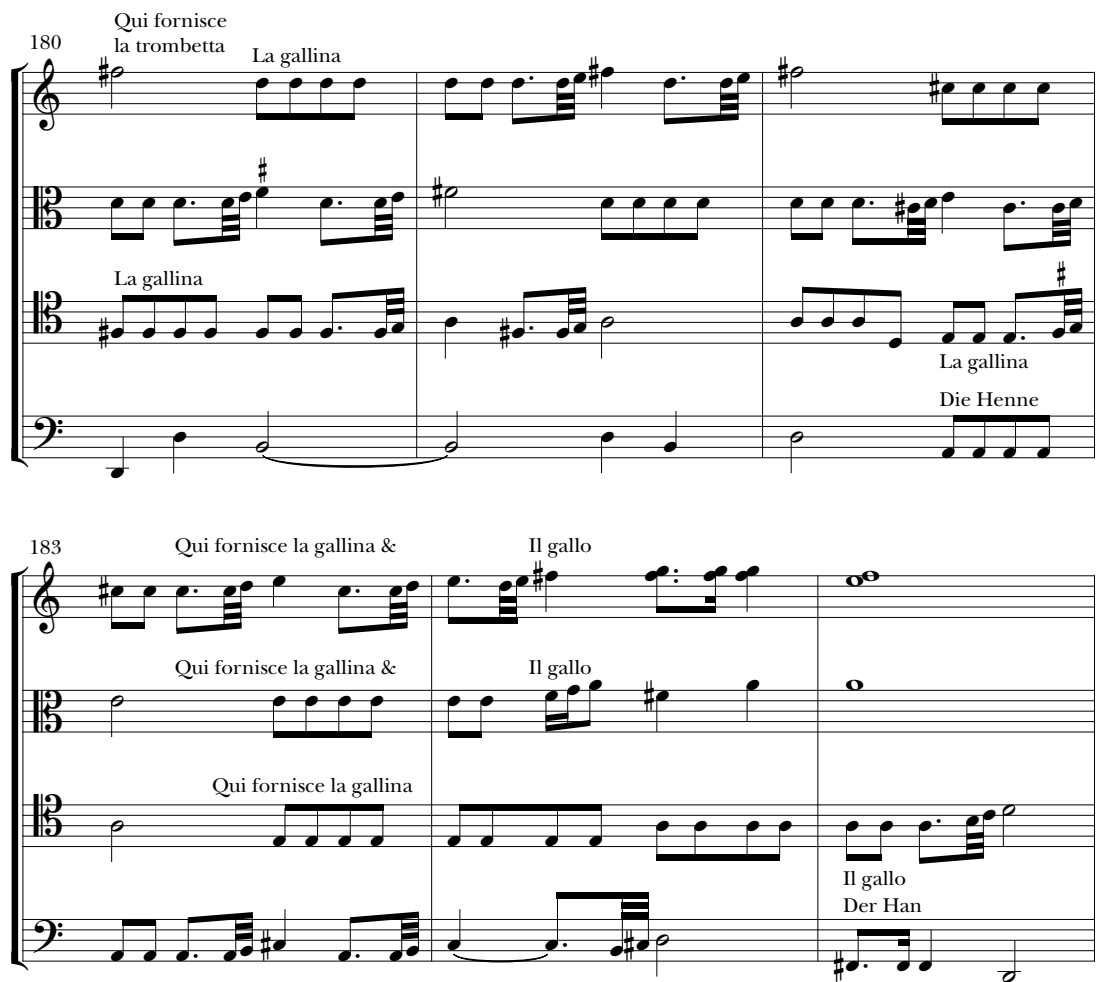

But surprising harmonies also occur in non-illustrative passages. Following the music of the flautino (played sul ponticello), which ends on a B-minor chord, a new section employing the dactylic fanfare rhythm of the opening begins in B major, a key that would surely have sounded harsh-even shocking-in the mean-tone temperament likely used in performance (see ex. 10).

In other passages, non-illustative music leads directly to illustrative sections, further blurring the distinction between them. A duplemeter section of non-illustrative music uses rhythms that foreshadow the passage that follows, which imitates an organ tremulant. At the beginning of the section the strings alternate eighth-note figures; these slow to quarters as shown in example 11 . The bass instrument continues playing quarter notes in its melody in the tremulant section $(\mathrm{m}$. 244), and although the upper-string parts are notated with large notevalues, Farina's performance instructions indicate that "Il tremolo và 
EXAMPLE 10. "Il flautino" and following section from Farina, Capriccio stravagante, mm. 201-207

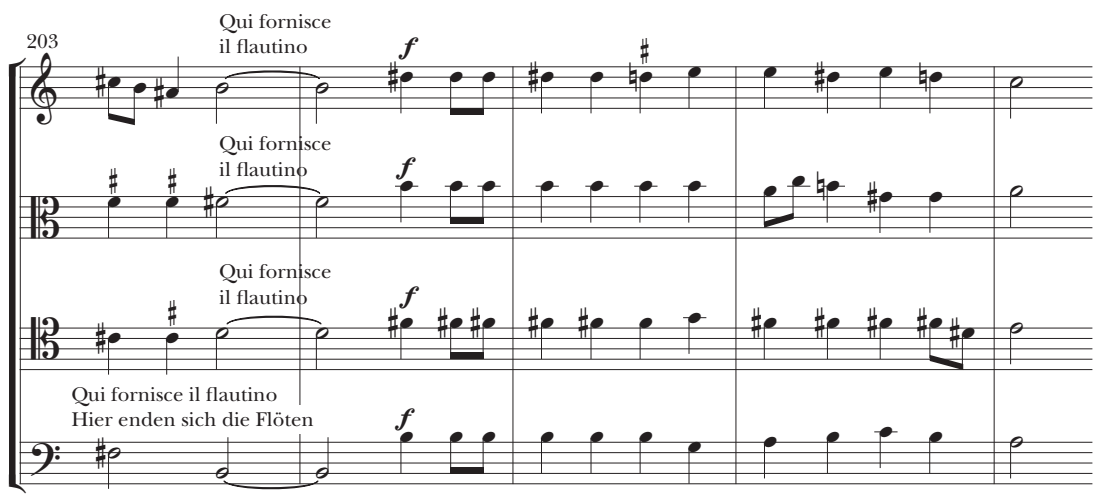

sonato solamente facendo tremar il pulso della mano dell'Archetto" (The tremulant is played simply by making the pulse of the bow-hand tremble). In imitation of the even undulation of volume caused by an organ tremulant, the string players thus use a measured bow tremolo to divide their notes, probably into even eighths (see ex. 11).$^{5^{1}}$

This section as a whole integrates illustrative and non-illustrative music, and the line between them is further confused by the harmonic trajectory of the tremulant passage. In this humorous depiction of the inexperienced organist, harmonic confusion serves to represent the insecurity of the performer apparently in the middle of an improvisation. At more than one point he plays wrong notes (see the first beat of m. $25^{8}$ and m. 262), falling prey to one of the dangers of live performance, and in doing so he calls the audience's attention to the risky nature of improvisation and of music-making in general.

Thus, like the quasi-improvisatory music of Monteverdi, Frescobaldi, Marini, and Castello, Farina's Capriccio explores the relationship between extempore performance and composition, self-consciously highlighting the precarious nature of music-making. Even though the Capriccio does not make use of the wild, rhapsodic idiom of the stilemoderno sonata, it moves so freely and unpredictably between illustrative and non-illustrative sections, between unmarked dance music and surprising virtuosic techniques, that it seems at least quixotic. Whether or not the unpredictability of the Capriccio is meant to allude to improvisatory practices, it projects a sense of spontaneity, as if the performers

$5^{1}$ On the performance of tremolo in the seventeenth century, see Stewart Carter, "The String Tremolo in the $17^{\text {th }}$ Century," Early Music 19, no. 1 (February 1991): 43-6o. 
EXAMPLE 11. "Il tremulo" from Farina, Capriccio stravagante, mm. 240-266
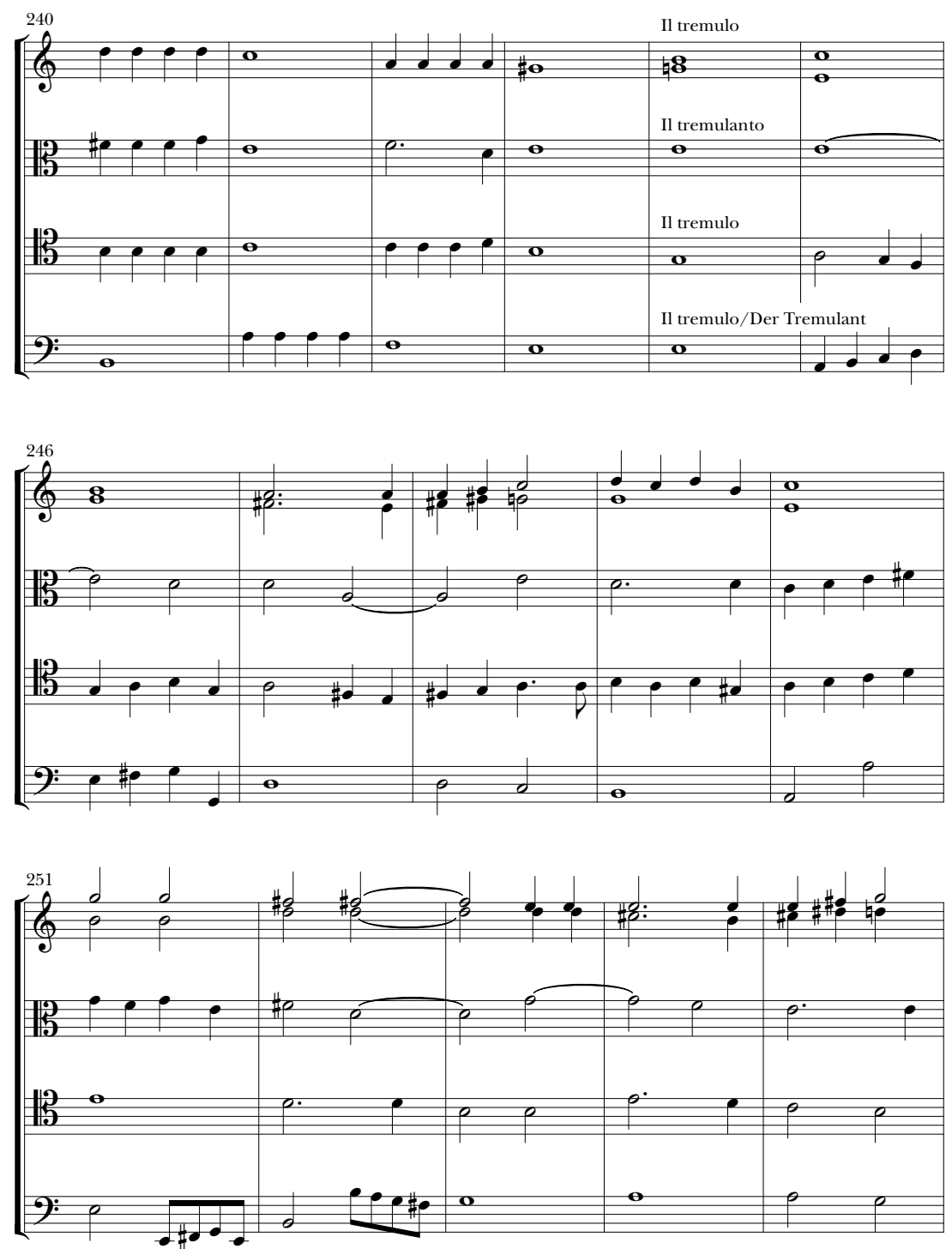

themselves hardly knew where their imaginations will take them. Although its structure and program might at first seem unplanned, even incoherent, they may actually signify an attempt on Farina's part to probe the interaction between extemporaneous invention and planned composition. 
EXAMPLE 11. (continued)
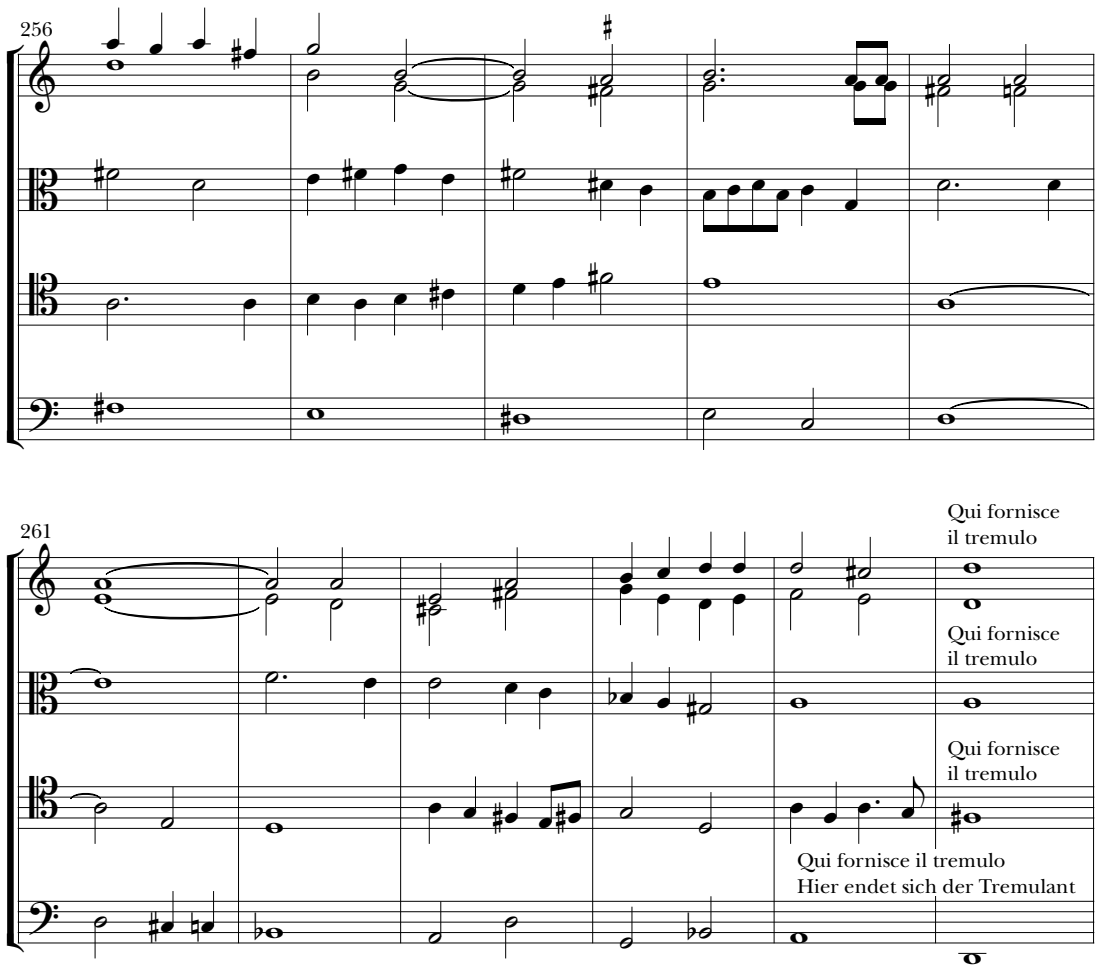

The relationship between string players performing Farina's Capriccio and the imaginary organist of the tremulant section further problematizes the issue of role-play in instrumental music. Some of the instruments that the violin family is called upon to imitate are not far afield; the idea of string players imitating a lira, for example, is quite plausible. So is the imitation of an organ, even though four players must act as one; with the right tone and the use of measured tremolo the instruments may sound similar.

Other compositional devices and performing techniques allow the violin-family to represent instruments to which it is less closely related; bowing sul ponticello, for example, allows the instruments to capture the sound of flautino. These passages allude to an alternate musical reality; the players exploit their own instruments to enter the sound-worlds of others. Indeed, Farina's tour of instruments foreshadows Doni's description of the violin's capacity to capture external sounds and affects. The capacities of the instrumentalists as actors are taxed to the extreme. 
Farina's performers do not portray a real plot, as operatic singers would do. Instead, the Capriccio is about the instruments themselves: the interest of the piece lies in its representation of unusual sounds, and in the techniques that enable that representation. As in Marini's collection, the virtuosic Inventionen appear at the moments when Farina's representational project is at its height.

\section{An Instrumental Stile rappresentativo?}

Farina's Capriccio stravagante had a successor in the latter half of the seventeenth century: Johann Heinrich Schmelzer's Sonata representativa (c. 1669). $5^{2}$ Like Farina's composition, Schmelzer's work uses virtuosic violin techniques to imitate the natural sounds of other instruments and of animals. That Schmelzer calls his work "representational" is noteworthy, since the term is rarely attached directly to a work of instrumental music. Nevertheless, other written evidence exists to suggest that composers and theorists saw links between the vocal stile rappresentativo and the instrumental stile moderno of the 161 os and '2os. The passage by Kircher quoted at the beginning of this essay suggests that instrumental music could call to mind intense emotions and vivid images. According to Doni the violin represents (rappresenta) the sounds and affects of other instruments, so that, despite its unassuming physical construction, it has the same capacity for imitation as the organ. That Frescobaldi's description of the metrical flexibility of his toccatas (hor languida, hor veloce . . . secondo $i$ loro affetti) is closely related to, or perhaps even modeled upon, Peri's explanation of the bass line of recitative (hor più, hor meno secondo gli affetti)-developed for use in theatrical presentations-further underscores the relationship of the instrumental style to the vocal stile rappresentativo. This association comes into sharper focus through the comparison of Frescobaldi's preface with the rubric attached to Monteverdi's Lettera amorosa "Se' i languidi i miei sguardi" (1619): "in genere rappresentativo e si canta senza battuta" (in the representational genus, and sung without [a steady] beat). In Monteverdi's music, like Frescobaldi's toccatas, the representational style is tied up with an undermining or abandonment of the battuta. 53

$5^{2}$ That the Sonata representativa is by Schmelzer and not, as thought earlier, by Biber, was demonstrated by Charles Brewer in his paper, "The Case of the Fallacious Fauna: Biber, Schmelzer and the Sonata violino solo rappresentativa," read at the 1998 meeting of the Society for Seventeenth-Century Music. Abstract available at http:/ /www.arts.uci.edu/ sscm/archives/2001.html\#Brewer (accessed 13 March 2010).

53 Monteverdi, Concerto: settimo libro dei madrigali, con altri generi de canti (Venice: Bartolomeo Magni, 1619). Modern edition in Monteverdi, Concerto, settimo libro dei madrigali, ed. Anna Maria de Chiara (Cremona: Fondazione Claudio Monteverdi, 20o8). 
Even more clearly than these sparse pieces of verbal evidence, the music itself provides a link between the instrumental stile moderno and the vocal stile rappresentativo. Indeed, the points of intersection between vocal and instrumental music raised thus far form a constellation that seems remarkably consistent with characteristics of the stile rappresentativo. First, in the repertoire of the 1610 and '2os, instrumentalists sometimes use their virtuosity in a theatrical manner; they engage in moments of role-play, they imitate sounds of nature and of other instruments, they use staging, movement, and props to define their interaction with an audience, and they call attention self-consciously to the act of performance itself. Second, the works often require rhythmic and metrical flexibility, which in turn aids in the portrayal of emotional content; musical material changes quixotically, projecting a sense of affective spontaneity. Third, this sense of musical impulsiveness is aided by the musical texts, which appear at times to serve as records of improvisation or as aids in the execution of a quasi-improvisatory style, in which musical contrast assumes a role of primary importance.

The inconsistent use of the terminology surrounding the stile rappresentativo, the stile recitativo, and related idioms, and debates concerning 220 the meanings of those expressions persisted well into the century.54 It is possible, in fact, that composers of the early seventeenth century saw the stile rappresentativo as encompassing a collection of interrelated-but not necessarily interdependent-characteristics, many of which parallel aspects of the instrumental stile moderno.

Two works by Monteverdi that the composer classifies in the genere rappresentativo-one from his seventh book of madrigals and one from his eighth-help clarify the meaning of the vocal stile rappresentativo, and also strengthen connections between that style and the instrumental repertoire.

As noted earlier, "Se'i languidi i miei sguardi" bears a rubric that suggests a distinction between the mode of execution ("si canta senza battuta" and the programmatic description and generic classification of the piece (Lettera amorosa . . . in genere rappresentativo). The rubric implies that the genere rappresentativo does not necessarily include an abandonment of the battuta; if metrical flexibility were a requirement of the style, then the rubric would be redundant. Instead, as in this case, representational music may employ metrical flexibility to achieve dramatic goals.

54 For example, as late as 1640 Doni's Annotazioni included an essay on the stillconfused terminology. See Carter, "Resemblance and Representation"; see also Carter, "The Search for Musical Meaning," in The Cambridge History of Seventeenth-Century Music (Cambridge: Cambridge University Press, 2005), 189-97. 
That the Lettera amorosa is not staged or is not obviously theatrical, despite its classification as part of the stile rappresentativo, does not pose a problem. Overt theatricality was, again, just one aspect of the stile rappresentativo, obviously not required for the inclusion of a piece in the category. Rather, the representational quality of the Lettera amorosa is apparently rooted in its emotional outpouring-in its representation of a series of intense affects. This emotive syntax, which facilitates a rhetoric of immediacy and perhaps even a posture of improvisation, finds its parallel in Frescobaldi's toccatas, in Marini's "Sonata variata," and in Castello's "Sonata prima," described above. .55

Like the Lettera amorosa, Monteverdi's Combattimento di Tancredi e Clorinda, premiered in 1624 and published in his Madrigali guerrieri, et amorosi of 1638 , is classified in the genere rappresentativo. What makes this piece representational, however, is entirely different. Most obviously, unlike the Lettera amorosa, this piece is staged; it involves plot, characters, movement, and props. Although at certain points the narrator may take rhythmic or metrical liberty, recitative per se is not an essential part of the work.

Moreover, like some instrumental works described above, Il Combattimento includes a moment of metatheatricality. The presence of an epic narrator-the speaker who weaves together the subplots of Tasso's Gerusalemme liberata - calls attention to the dramatic presentation of the piece. After two introductory stanzas in which the scene is set, the narrator suspends the action to address the personified Night who "encloses in profound darkness this great feat." He describes the battle between Tancredi and Clorinda as "worthy of clear sunlight, worthy of a full theater," and asks for permission to tell the story "for future ages." ${ }^{6}$

55 An interpretation of the Lettera amorosa as a representation of musical invention resonates with Doni's (unfavorable) description of the work and its companion piece, the Partenza amorosa: "The invention of the Lettere has more of the capricious than the reasonable: for although both are recounted, as we are to believe, to some lady who knows how to sing and play, however it does not seem good that that which the lover should say or sing should be sung by the woman" (italics mine). Doni, Lyra barberina amphichordos, eds., A. F. Gori and G. B. Passeri (Florence: $1763 /$ R), 26ff. Quoted in Hans Ferdinand Redlich, Claudio Monteverdi: Ein formengeschichtlicher Versuch, vol. 1 (Hildesheim: Olms, 1976), 135, translated by Carter in Fabbri, Monteverdi, 167. Doni's criticism rests on his understanding-presumably of both music and text-that Monteverdi's Lettera amorosa originates from the male singer and cannot or should not be replicated by his beloved. His characterization of the work as "capricious" rather than "reasonable" seems particularly significant: the work is, like the stile-moderno instrumental sonata, unpredictable, volatile, and irregular.

$5^{6}$ Text adapted from Torquato Tasso, Gerusalemme liberata XII/54. Monteverdi emphasizes this metatheatrical moment in multiple ways. First, his introduction to the Combattimento instructs the narrator that "He should not perform runs or trills anywhere else but in the stanza beginning 'Notte.'” (Non doverà far gorghe nè trilli in altro loco, che solamente nel canto de la stanza, che incomincia Notte.) In addition, Monteverdi changes the order of the couplets in that stanza from Tasso's text, so that the invocation 
By referring to himself as the controller of information and perpetuator of the tale, the narrator breaks down the wall between himself and the audience. His reference to the theater calls further attention to the staging of the work and to the dramatic enterprise as a whole.

Taken together, the Lettera amorosa and the Combattimento offer complementary snapshots of the vocal stile rappresentativo, both of which find parallels in stile-moderno instrumental music. The first piece represents not a plot, but a set of highly-charged emotions, ordered in an almost impulsive-in Doni's words "capricious"-fashion. The stile recitativo, with its metrical flexibility designed to imitate speech, enhances the work's musical expression, and also lends the work an air of immediacy. Here the term stile rappresentativo refers to an abstract concept-expression of the affetti. Instrumental works by Marini, Castello, and others bear similar characteristics: metrical fluidity, surface unpredictability of musical material, and heightened affective content. In the Combattimento, by contrast, all the tangible aspects of theatrical music-costumes, sets, props, staging, role-play, movement-come into play. And the work reflexively, self-consciously, one might say metatheatrically, comments upon itself as a representational undertaking. The inventioni of Marini and Farina likewise call attention to the physical actions involved in performance, and more important, to the instruments themselves as vehicles for representation.

The relative silence of theoretical writers thus does not disprove the existence of an instrumental stile rappresentativo, but may instead be attributed to their silence on instrumental music altogether. Indeed, the sources that do survive-Doni's essay, prefaces by Frescobaldi and Castello, rubrics linked to music by Marini and Farina, and most significantly, the musical works themselves-indicate that representation of emotions, and, more broadly, theatrical representation, were of primary concern to instrumental composers of the early Seicento.

New England Conservatory

\footnotetext{
of Night starts the stanza, rather than appearing in the second couplet; this change calls greater attention to the narrator's shift in address. Monteverdi's text reads "Notte, che nel profondo oscuro seno / chiudesti e nell'oblio fatto sì grande, / Degne d'un chiaro sol, degno d'un pieno / teatro opre sarian sì memorande, / Piacciati ch'indi il tragga e 'n bel sereno / alle future età lo spieghi e mande. / Viva la fama lor e tra lor gloria / splenda del fosco tuo l'alta memoria." Tasso's stanza 54 opens with the couplet beginning "Degne d'un chiaro sol." Monteverdi, Madrigali guerrieri, et amorosi con alcuni opuscoli in genere rappresentativo (Venice: Alessandro Vincenti, 1638). Modern edition of the Combattimento in Monteverdi, Madrigali guerrieri, et amorosi: libro ottavo, ed. Anna Maria Vachelli (Cremona: Fondazione Claudio Monteverdi, 2004). Translations of texts and rubrics by Stanley Appelbaum in Gian Francesco Malipiero, ed., Claudio Monteverdi: Madrigals Book VIII (Madrigali guerrieri et amorosi) (New York: Dover Publications, 1991/R), xvii-xviii.
} 


\begin{abstract}
Several points of intersection exist between vocal and instrumental music by Italian composers of the early seventeenth century. First, like books of vocal monody with an overt pedagogical purpose, volumes of instrumental music may have been designed to instruct the performer in the conventions of the modern style. Specifically, many books published in the 1610 and ' 20 offer their users a window on the changeable, fluid idiom of the stile moderno, in which contrast of musical material and a posture of invention assumes primary importance. Second, as in recitative and other vocal styles, much of the vocal and instrumental music of the early seventeenth century is dominated by a metrical flexibility that similarly contributes to an air of immediacy, and that seems designed to highlight the emotional qualities of the music-to convey and move the affetti. And third, whereas the theatrical nature of vocal music of the period-especially music destined for the stage-may appear obvious, some instrumental music of the period may be equally theatrical, containing instructions for interaction with an audience, staging, imitation, and role-play.

These points of intersection in particular suggest a relationship between the instrumental stile moderno and the vocal stile rappresentativo, prevalent in operas, ensemble madrigals, and solo songs in the early 1600 . Although no single, exclusive definition of the stile rappresentativo exists, it is nevertheless possible to trace a constellation of features associated with that term through a variety of works. Despite the divergence of the specific musical language of the vocal and instrumental repertoires, some of the vocal features are analogous to elements of instrumental music discussed in the article.
\end{abstract}

Keywords: Giovanni Battista Doni, Dario Castello, Carlo Farina, Biagio Marini, stile moderno, stile rappresentativo 